\title{
Fluorescent poly(boron enaminoketonate)s: synthesis via the direct modification of polyisoxazoles obtained from the click polymerization of a homoditopic nitrile $\mathbf{N}$-oxide and diynes
}

\author{
Tohru Matsumura $^{1}$, Yasuhito Koyama ${ }^{2}$, Satoshi Uchida ${ }^{1}$, Morio Yonekawa ${ }^{1}$, Tatsuto Yui ${ }^{3}$, Osamu Ishitani ${ }^{4}$ and \\ Toshikazu Takata ${ }^{1}$ \\ Fluorescent poly(boron enaminoketonate)s (PBEKs) were synthesized via the polycycloaddition of a homoditopic nitrile $\mathrm{N}$-oxide \\ to diynes followed by other polymer reactions. Click polycycloaddition of the nitrile $\mathbf{N}$-oxide to various diynes effectively \\ produced polyisoxazoles in high yields. The polyisoxazoles were transformed into the corresponding fluorescent PBEKs by \\ forming the poly( $\beta$-aminoenone) intermediates and reacting these intermediates with $\left(\mathrm{C}_{6} \mathrm{~F}_{5}\right)_{2} \mathrm{BF}$. OEt $\mathrm{E}_{2}$. The solution and \\ solid-state optical properties of the PBEKs were evaluated by ultraviolet-visible (UV-vis) and fluorescence spectroscopy. \\ Polymer Journal (2014) 46, 609-616; doi:10.1038/pj.2014.31; published online 14 May 2014
}

Keywords: click polymerization; fluorescence; homoditopic nitrile $\mathrm{N}$-oxide; poly(boron enaminoketonate); polyisoxazole

\section{INTRODUCTION}

Boron diketonates constitute a family of boron-chelating dyes and, as fluorophores, they have attracted much attention. ${ }^{1-4}$ The optical properties of boron diketonates, such as large Stokes shifts and two-photon absorption cross-sections, and their incorporation into various organic backbones make them potentially useful in molecular probe $^{5}$ laser $^{6}$ and optical-sensing applications. ${ }^{7,8}$ In the polymeric materials field, Fraser and colleagues ${ }^{9}$ reported the synthesis of a boron diketonate-containing polylactide and described its oxygensensing property. Moreover, Chujo and colleagues ${ }^{10-12}$ demonstrated the synthesis and emission color tuning of main-chain-type poly(boron diketonate)s. However, the difficult synthesis of boron diketonate-containing polymers restricts their applicability. Therefore, substituting a boron diketonate with a boron enaminoketonate (BEK) is attractive because it is expected that the structurally analogous BEK would act as a fluorophore with good optical properties similar to those of the boron diketonate (for a related study concerning synthesis and spectral study of fluorescent BF2 complexes with 1,3-enaminoketone ligands, see Xia et al. $\left.{ }^{13}\right) .{ }^{14}$ Indeed, Chujo and colleagues $^{15}$ reported the optical properties of BEKs, such as large Stokes shifts and high molar absorption coefficients, that are quite similar to those of boron diketonates.

Recently, we reported a unique fluorescence control system consisting of a BEK placed at the end of a rotaxane axle. ${ }^{16}$
The rotaxane-based BEK was readily prepared by transforming an isoxazole-containing rotaxane that was synthesized via a stable nitrile $\mathrm{N}$-oxide-based click end-capping reaction. The BEK fluorescence maximum was red-shifted, and the fluorescence quantum yield was remarkably enhanced by the wheel translation to the fluorophore. We also developed a synthetic method to produce a poly( $\beta$-aminoenone) via the catalyst-free click polycycloaddition of a homoditopic nitrile $\mathrm{N}$-oxide to diynes and subsequent selective reduction of the $\mathrm{N}-\mathrm{O}$ bonds. ${ }^{17}$ Therefore, it should be possible to prepare a poly(boron enaminoketonate) (PBEK) by reacting a poly( $\beta$-aminoenone) with an organoboron complex via a synthetic protocol similar to that used to prepare the rotaxane-based BEK. Here, we describe the practical synthesis and properties of new fluorescent PBEKs. We emphasize the straightforward introduction of boron enaminoketonate backbones into a polymer main chain using the catalyst-free click polymerization of a homoditopic stable nitrile $\mathrm{N}$-oxide (Figure 1).

\section{EXPERIMENTAL PROCEDURE}

Materials

Dichloromethane was dried over freshly activated $4 \AA$ molecular sieves (MS $4 \AA$ ). Nitrile $N$-oxide $\mathrm{C}$ was prepared according to the literature. ${ }^{18}$ The formula numbers of all compounds given below are also used in the main text. Compounds that are not labeled in the main text are labeled with letters $(\mathbf{A}-\mathbf{K})$.

\footnotetext{
${ }^{1}$ Department of Organic and Polymeric Materials, Tokyo Institute of Technology, Tokyo, Japan; ${ }^{2}$ Catalysis Research Center, Hokkaido University, Sapporo, Japan; ${ }^{3}$ Department of Material Science and Technology, Faculty of Engineering, Niigata University, Niigata, Japan and ${ }^{4}$ Department of Chemistry, Tokyo Institute of Technology, Tokyo, Japan Correspondence: Dr Y Koyama, Catalysis Research Center, Hokkaido University, N21, W10, Kita-ku, Sapporo 001-0021, Japan.

E-mail: yasuhito.koyama@cat.hokudai.ac.jp

or Professor T Takata, Department of Organic and Polymeric Materials, Tokyo Institute of Technology, 2-12-1 (H-126), Ookayama, Meguro, Tokyo 152-8552, Japan. E-mail: ttakata@polymer.titech.ac.jp

Received 21 January 2014; revised 24 March 2014; accepted 24 March 2014; published online 14 May 2014
} 

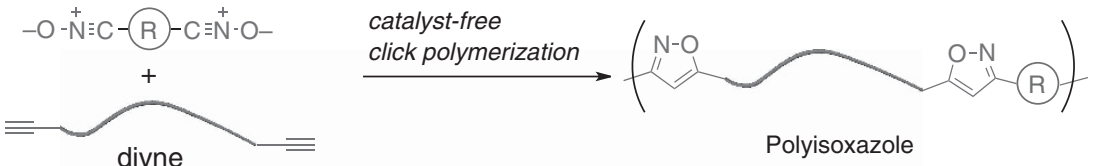

Polyisoxazole

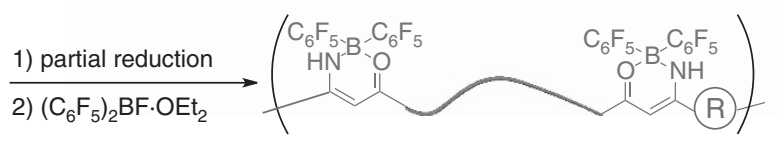

Poly(Boron Enaminoketonate)

Figure 1 Click polymerization utilizing a homoditopic nitrile $\mathrm{N}$-oxide and diyne and the transformation of a polyisoxazole into a fluorescent poly(boron enaminoketonate) (PBEK). A full color version of this figure is available at the Polymer Journal online.

\section{Measurements}

The ${ }^{1} \mathrm{H}(400 \mathrm{MHz}),{ }^{13} \mathrm{C}(100 \mathrm{MHz})$ and ${ }^{19} \mathrm{~F}(400 \mathrm{MHz})$ nuclear magnetic resonance (NMR) spectra were recorded on a JEOL AL-400 spectrometer (JEOL, Tokyo, Japan) using $\mathrm{CDCl}_{3}$ and DMSO- $d_{6}$ as the solvents. The ${ }^{1} \mathrm{H}$ and ${ }^{13} \mathrm{C}$ NMR spectra were calibrated using residual undeuterated solvent or tetramethylsilane as the internal standard. The ${ }^{19} \mathrm{~F}$ NMR spectra were calibrated using $\mathrm{CFCl}_{3}$ or fluorobenzene as the internal standard. Infrared (IR) spectra were recorded on a JASCO FT/IR-230 spectrometer (JASCO, Tokyo, Japan). Melting points were measured using a Melting Point Apparatus SMP3 (Stuart Scientific, Staffordshire, UK) instrument. Matrix-assisted laser desorption/ionization time-of-flight mass spectrometry (MALDI-TOF MS) was measured with a Shimadzu AXIMA-CFR mass spectrometer (Shimadzu, Kyoto, Japan) using a dithranol matrix. High-resolution fast atom bombardment mass spectra (FAB-HRMS) were recorded with an ICP-MS instrument (SPQ-9000; Seiko Instruments, Chiba, Japan) at the Center for Advanced Materials Analysis, Tokyo Institute of Technology by request. Ultravioletvisible (UV-vis) spectra of the PBEKs in solution were collected with a JASCO V-550 spectrophotometer (JASCO). Fluorescence emission spectra of the PBEKs in solution were recorded with a JASCO FP-6500 spectrofluorometer (JASCO), and the quantum yields were calculated using the fluorescence intensity of 9,10-diphenylanthracene as a reference standard. To evaluate the solid-state PBEK UV-vis and emission spectra, the polymer (poly-3 or PEG-3) was first dispersed in $2.5 \mathrm{ml}$ of an Ar-saturated cyclohexane solution $\left(0.3 \mathrm{mg} \mathrm{ml}^{-1}\right)$ by reprecipitating a polymer solution in $\mathrm{CH}_{2} \mathrm{Cl}_{2}(0.2 \mathrm{ml})$. The emission spectra and quantum yields were then measured using a calibrated integrating sphere and multi-channel spectrometer (C9920-02G, Hamamatsu Photonics, Hamamatsu, Japan) under $388 \mathrm{~nm}$ excitation. The emission quantum yields were obtained using the emission intensities in the 400 $800 \mathrm{~nm}$ region.

Synthesis of the model compounds used to evaluate the optical properties Synthesis of 1-methoxy-4-trimethylsilylethynylbenzene A. Trimethylsilylacetylene $(5.00 \mathrm{ml}, 36.1 \mathrm{mmol})$ was added to a suspension of 1-iodo-4-methoxybenzene $(4.58 \mathrm{~g}, 24.5 \mathrm{mmol}), \mathrm{Pd}\left(\mathrm{PPh}_{3}\right)_{4}(844 \mathrm{mg}, 0.73 \mathrm{mmol})$ and $\mathrm{CuI}$ $(140 \mathrm{mg}, 0.73 \mathrm{mmol})$ in $\mathrm{Et}_{3} \mathrm{~N}(80 \mathrm{ml})$ at room temperature. ${ }^{19}$ The mixture was heated to $80^{\circ} \mathrm{C}$, stirred for $3 \mathrm{~h}$ under an argon atmosphere, filtered and concentrated in vacuo. The crude product was purified by silica gel column chromatography (hexane/ethyl acetate $=9: 1)$ to give A $(5.85 \mathrm{~g}, 28.6 \mathrm{mmol}$, quantitative yield (quant.)) as a brown oil: ${ }^{1} \mathrm{H} \mathrm{NMR}\left(400 \mathrm{MHz}, 298 \mathrm{~K}, \mathrm{CDCl}_{3}\right)$ $\delta 7.40(\mathrm{~d}, J=9.0 \mathrm{~Hz}, 2 \mathrm{H}), 6.81(\mathrm{~d}, J=9.0 \mathrm{~Hz}, 2 \mathrm{H}), 3.81(\mathrm{~s}, 3 \mathrm{H})$ and $0.24(\mathrm{~s}$, 9H) p.p.m.

Synthesis of 1-methoxy-4-ethynylbenzene B. $\mathrm{K}_{2} \mathrm{CO}_{3}(6.77 \mathrm{~g}, 49.0 \mathrm{mmol})$ was added to a solution of $\mathbf{A}(5.85 \mathrm{~g}, 24.5 \mathrm{mmol})$ in $\mathrm{MeOH}(100 \mathrm{ml})$ at room temperature. The mixture was heated to $40^{\circ} \mathrm{C}$, stirred for $3 \mathrm{~h}$ under an argon atmosphere and concentrated in vacuo. Saturated aqueous $\mathrm{NaHCO}_{3}(150 \mathrm{ml})$ was added to the mixture, and the products were extracted with EtOAc. The combined organic layer was dried over $\mathrm{Na}_{2} \mathrm{SO}_{4}$, filtered and concentrated in vacuo. The crude product was purified by short flash column chromatography on silica gel (hexane/EtOAc $=9: 1)$ to yield $\mathbf{B}(3.07 \mathrm{~g}, 23.2 \mathrm{mmol}, 95 \%)$ as a brown oil. The crude was used in the next reaction without further purification: IR $(\mathrm{NaCl})$ v 3287, 3004, 2959, 2837, 2540, 2106, 1893, 1606,
$1571,1505,1464,1442,1291,1249,1171,1108,1031,833,641,606$ and $537 \mathrm{~cm}^{-1}$; ${ }^{1} \mathrm{H}$ NMR $\left(400 \mathrm{MHz}, 298 \mathrm{~K}, \mathrm{CDCl}_{3}\right) \delta 7.43(\mathrm{~d}, J=8.9 \mathrm{~Hz}, 2 \mathrm{H}), 6.84$ (d, $J=8.9 \mathrm{~Hz}, 2 \mathrm{H}), 3.81$ (s, 3H), 3.00 (s, 1H) p.p.m.; ${ }^{13} \mathrm{C} \mathrm{NMR}(100 \mathrm{MHz}$, $\left.298 \mathrm{~K}, \mathrm{CDCl}_{3}\right) \delta 160.1,133.8,114.3,114.1,83.9,76.2$ and 55.3 p.p.m.

Synthesis of pentafluorophenyl magnesium bromide. Bromopentafluorobenzene $(2.10 \mathrm{ml}, 16.6 \mathrm{ml})$ was added dropwise to a solution of magnesium $(392 \mathrm{mg}, 16.1 \mathrm{mmol})$ in $\mathrm{Et}_{2} \mathrm{O}(30 \mathrm{ml})$ under an argon atmosphere at room temperature, and the mixture was refluxed for $3 \mathrm{~h}$ to give pentafluorophenyl magnesium bromide. ${ }^{20}$ This crude product was used in the next reaction without purification.

Synthesis of $\left(\mathrm{C}_{6} \mathrm{~F}_{5}\right)_{2} \mathrm{BF} \cdot \mathrm{OEt}_{2}$ 5. The freshly prepared $\mathrm{C}_{6} \mathrm{~F}_{5} \mathrm{MgBr}$ solution in $\mathrm{Et}_{2} \mathrm{O}(30 \mathrm{ml})$ was added all at once to a solution of $\mathrm{BF}_{3} \cdot \mathrm{OEt}_{2}(1.02 \mathrm{ml}$, $8.04 \mathrm{mmol})$ in $\mathrm{Et}_{2} \mathrm{O}(20 \mathrm{ml})$ at $0{ }^{\circ} \mathrm{C} .{ }^{20}$ After stirring for $30 \mathrm{~min}$, the solvent was evaporated at $0{ }^{\circ} \mathrm{C}$ to give $\mathbf{5}$ as a gray solid. This crude solid was used in subsequent reaction without purification.

Synthesis of isoxazole D. Nitrile $\mathrm{N}$-oxide C $(500 \mathrm{mg}, 2.51 \mathrm{mmol})$ was added to a solution of 4-ethynylanisole $(498 \mathrm{mg}, 3.77 \mathrm{mmol})$ in $\mathrm{CHCl}_{3}(10 \mathrm{ml})$. The solution was refluxed for $5 \mathrm{~h}$. The crude product was purified by short flash column chromatography on silica gel (hexane, then $\mathrm{CHCl}_{3}$ ) to yield $\mathbf{D}$ (588 mg, $1.77 \mathrm{mmol}, 71 \%$ ) as a light brown solid: m.p. $96.9-97.9{ }^{\circ} \mathrm{C}$; IR (potassium bromide $(\mathrm{KBr})$ ) v 2935, 2835, 1613, 1512, 1433, 1353, 1304, 1254, $1176,1078,1026,835,804,752$ and $655 \mathrm{~cm}^{-1}$; ${ }^{1} \mathrm{H}$ NMR $(400 \mathrm{MHz}, 298 \mathrm{~K}$, $\left.\mathrm{CDCl}_{3}\right) \delta 7.97(\mathrm{~d}, J=8.2 \mathrm{~Hz}, 1 \mathrm{H}), 7.91(\mathrm{~d}, J=8.6 \mathrm{~Hz}, 1 \mathrm{H}), 7.83(\mathrm{~d}, J=9.0 \mathrm{~Hz}$, $1 \mathrm{H}), 7.83(\mathrm{~d}, J=9.0 \mathrm{~Hz}, 2 \mathrm{H}), 7.45(\mathrm{dd} ;=8.2,6.8 \mathrm{~Hz} ; 1 \mathrm{H}), 7.38(\mathrm{dd} ; J=8.6$, $6.8 \mathrm{~Hz} ; 1 \mathrm{H}), 7.37(\mathrm{~d}, J=9.0 \mathrm{~Hz}, 1 \mathrm{H}), 7.02(\mathrm{~d}, J=9.0 \mathrm{~Hz}, 2 \mathrm{H}), 6.61(\mathrm{~s}, 1 \mathrm{H})$ $3.94(\mathrm{~s}, 3 \mathrm{H})$ and 3.89 (s, 3H) p.p.m.; MALDI-TOF MS (matrix/dithranol) calculated (calcd.) for $\mathrm{C}_{21} \mathrm{H}_{17} \mathrm{NO}_{3}[\mathrm{M}+\mathrm{Na}]^{+}$: 354.11, found: 354.09 .

Synthesis of enaminoketone E. $\mathrm{Mo}(\mathrm{CO})_{6}(191 \mathrm{mg}, 0.725 \mathrm{mmol})$ was added to a solution of isoxazole $\mathbf{D}(200 \mathrm{mg}, 0.604 \mathrm{mmol})$ in $\mathrm{CH}_{3} \mathrm{CN}(5 \mathrm{ml})$ and water $(1.2 \mathrm{ml})$. The mixture was refluxed for $10 \mathrm{~h}$ and then evaporated in vacuo. The crude product was purified by short flash column chromatography on silica gel (hexane/EtOAc $=2: 1)$ to yield $\mathbf{E}(174 \mathrm{mg}, 0.522 \mathrm{mmol}, 86 \%)$ as a brown solid. The crude was used in the next reaction without further purification: IR (KBr) v $3449,2935,2838,1595,1503,1378,1252,1174,1076$ and $1028 \mathrm{~cm}^{-1} ;{ }^{1} \mathrm{H}$ NMR $\left(400 \mathrm{MHz}, 298 \mathrm{~K}, \mathrm{CDCl}_{3}\right) \delta 10.50(\mathrm{br}, 1 \mathrm{H}), 8.00(\mathrm{~d}, J=8.5 \mathrm{~Hz}, 1 \mathrm{H}), 7.93$ $(\mathrm{d}, J=8.5 \mathrm{~Hz}, 1 \mathrm{H}), 7.90(\mathrm{~d}, J=9.0 \mathrm{~Hz}, 2 \mathrm{H}), 7.82(\mathrm{~d}, J=8.7 \mathrm{~Hz}, 1 \mathrm{H}), 7.47(\mathrm{dd} ;$ $J=8.5,6.9 \mathrm{~Hz} ; 1 \mathrm{H}), 7.38(\mathrm{dd} ; J=8.5,6.9 \mathrm{~Hz} ; 1 \mathrm{H}), 7.34(\mathrm{~d}, J=8.7 \mathrm{~Hz}, 1 \mathrm{H})$, $6.89(\mathrm{~d}, J=9.0 \mathrm{~Hz}, 2 \mathrm{H}), 5.92(\mathrm{~s}, 1 \mathrm{H}), 5.32(\mathrm{br}, 1 \mathrm{H}), 3.97(\mathrm{~s}, 3 \mathrm{H})$ and 3.84 (s, 3H) p.p.m.

Synthesis of 6. $\left(\mathrm{C}_{6} \mathrm{H}_{5}\right)_{2} \mathrm{BF} \cdot \mathrm{OEt}_{2}(5,70.5 \mathrm{mg}, 0.161 \mathrm{mmol})$ was added to a solution of $\mathbf{E}(10.3 \mathrm{mg}, 33.1 \mu \mathrm{mol})$ in $\mathrm{CH}_{2} \mathrm{Cl}_{2}(0.5 \mathrm{ml})$ under an argon atmosphere. The reaction mixture was stirred at room temperature for $2 \mathrm{~h}$ and then concentrated in vacuo. The crude product was purified by short flash column chromatography on silica gel $\left(\mathrm{CHCl}_{3}\right)$ and then by high-performance liquid chromatography to yield $6(22.3 \mathrm{mg}, 32.9 \mu \mathrm{mol}, 99 \%)$ as a yellow solid: m.p. 83.2-84.6 ${ }^{\circ}$; IR (KBr) v 3422, 2937, 2844, 1654, 1607, 1508, 1477, 1377, 1261, 1178, 1090, 979, 811, 797 and $752 \mathrm{~cm}^{-1}$; ${ }^{1} \mathrm{H}$ NMR $(400 \mathrm{MHz}, 298 \mathrm{~K}$, $\left.\mathrm{CDCl}_{3}\right) \delta 8.01(\mathrm{~d}, J=8.6 \mathrm{~Hz}, 2 \mathrm{H}), 8.00(\mathrm{~d}, J=9.3 \mathrm{~Hz}, 1 \mathrm{H}), 7.85(\mathrm{~d}, J=8.0 \mathrm{~Hz}$, 
1H), $7.81(\mathrm{br}, 1 \mathrm{H}), 7.68(\mathrm{~d}, J=8.4 \mathrm{~Hz}, 1 \mathrm{H}), 7.48(\mathrm{dd} ; J=8.4,7.0 \mathrm{~Hz} ; 1 \mathrm{H}), 7.42$ $(\mathrm{dd} ; J=8.0,7.0 \mathrm{~Hz} ; 1 \mathrm{H}), 7.34(\mathrm{~d}, J=9.3 \mathrm{~Hz}, 1 \mathrm{H}), 6.97(\mathrm{~d}, J=8.6 \mathrm{~Hz}, 2 \mathrm{H}), 6.15$ (s, $1 \mathrm{H}), 3.89(\mathrm{~s}, 3 \mathrm{H})$ and 3.88 (s, 3H) p.p.m.; ${ }^{13} \mathrm{C}$ NMR $(100 \mathrm{MHz}, 298 \mathrm{~K}$, $\left.\mathrm{CDCl}_{3}\right) \delta 173.7,168.5,164.0,154.6,133.3,131.4,130.7,129.0,128.9,128.5$, $126.0,124.9,123.8,118.2,114.5,113.0,96.0,56.6$ and 55.9 p.p.m.; ${ }^{19} \mathrm{~F}$ NMR $\left(400 \mathrm{MHz}, 298 \mathrm{~K}, \mathrm{CDCl}_{3}\right) \delta-137.25(\mathrm{~s}, 2 \mathrm{~F}),-157.99(\mathrm{~s}, 1 \mathrm{~F})$ and $-164.19(\mathrm{~s}, 2 \mathrm{~F})$ p.p.m.; MALDI-TOF MS (matrix/dithranol) calcd. for $\mathrm{C}_{33} \mathrm{H}_{18} \mathrm{BF}_{10} \mathrm{NO}_{3}$ $[\mathrm{M}+\mathrm{H}]^{+}:$: 678.13 , found: 678.14 .

Synthesis of bisaldehyde $\mathrm{F} . \quad \mathrm{K}_{2} \mathrm{CO}_{3}(15.2 \mathrm{~g}, 110 \mathrm{mmol})$ was added to a solution of 2-hydroxy-1-naphthaldehyde $(12.7 \mathrm{~g}, 73.8 \mathrm{mmol})$ and 1,8-dibromooctane $(6.76 \mathrm{ml}, 36.8 \mathrm{mmol})$ in dimethylformamide (DMF) $(40 \mathrm{ml})$ at room temperature. The mixture was refluxed for $5 \mathrm{~h}$. The mixture was cooled to room temperature, quenched by adding excess water and filtered. The crude product was recrystallized in $\mathrm{CHCl}_{3}$, and the resulting precipitate was washed with acetone to yield ditopic aldehyde F (13.4 g, $29.4 \mathrm{mmol}, 80 \%)$ as a pale pink solid: m.p. $161.3-165.2^{\circ} \mathrm{C}$; IR (KBr) v 2923, 2858, 1666, 1587, 1512, 1437, $1343,1249,1154,1058,814$ and $769 \mathrm{~cm}^{-1}$; ${ }^{1} \mathrm{H}$ NMR $\left(400 \mathrm{MHz}, 298 \mathrm{~K}, \mathrm{CDCl}_{3}\right)$ $\delta 10.93(\mathrm{~s}, 2 \mathrm{H}), 9.28(\mathrm{~d}, J=8.8 \mathrm{~Hz}, 2 \mathrm{H}), 8.04(\mathrm{~d}, J=9.2 \mathrm{~Hz}, 2 \mathrm{H}), 7.77(\mathrm{~d}$, $J=8.0 \mathrm{~Hz}, 2 \mathrm{H}), 7.63-7.60(\mathrm{~m}, 2 \mathrm{H}), 7.43-7.39(\mathrm{~m}, 2 \mathrm{H}), 7.28(\mathrm{~d}, J=9.2 \mathrm{~Hz}$, $2 \mathrm{H}), 4.23(\mathrm{t}, J=6.6 \mathrm{~Hz}, 4 \mathrm{H}), 1.90(\mathrm{tt} ; J=6.6,6.6 \mathrm{~Hz} ; 4 \mathrm{H}), 1.57-1.51(\mathrm{~m}, 4 \mathrm{H})$ and $1.45-1.41$ (m, 4H) p.p.m.; ${ }^{13} \mathrm{C}$ NMR $\left(100 \mathrm{MHz}, 298 \mathrm{~K}, \mathrm{CDCl}_{3}\right) \delta 192.3$, 163.9, 137.7, 131.7, 130.0, 128.6, 128.4, 125.1, 124.8, 116.9, 113.7, 69.6, 29.4, 29.4 and 26.2 p.p.m.; FAB-HRMS (matrix/NBA) calcd. for $\mathrm{C}_{30} \mathrm{H}_{31} \mathrm{NaO}_{4}[\mathrm{M}+$ $\mathrm{H}]^{+}:$455.2222, found: 455.2232

Synthesis of bisoxime G. A solution of $\mathrm{NH}_{2} \mathrm{OH} \cdot \mathrm{HCl}(6.22 \mathrm{~g}, 89.5 \mathrm{mmol})$ and $\mathrm{NaOH}(4.88 \mathrm{~g}, 120 \mathrm{mmol})$ in water $(150 \mathrm{ml})$ was added to a solution of ditopic aldehyde $\mathbf{F}(18.5 \mathrm{~g}, 40.7 \mathrm{mmol})$ in $\mathrm{EtOH}(150 \mathrm{ml})$ at $0{ }^{\circ} \mathrm{C}$. The mixture was heated to $60^{\circ} \mathrm{C}$ and stirred for $4 \mathrm{~h}$. The solution was cooled to room temperature and quenched by adding excess water. The resulting precipitate was filtered and washed with water, methanol and hot $\mathrm{CHCl}_{3}$ to yield ditopic oxime G $(0.800 \mathrm{~g}, 43.0 \mathrm{mmol}$, quant.) as a white solid. The crude was used in the next reaction without further purification: m.p. $159.6-164.5^{\circ} \mathrm{C}$; IR $(\mathrm{KBr}) \mathrm{v}$ 3297, 2941, 2857, 1632, 1593, 1513, 1463, 1440, 1318, 1247, 1181, 1063, 955, 914, 803, 751, 687 and $641 \mathrm{~cm}^{-1}$; ${ }^{1} \mathrm{H}$ NMR $\left(400 \mathrm{MHz}, 298 \mathrm{~K}, \mathrm{DMSO}-\mathrm{d}_{6}\right) \delta$ $11.31(\mathrm{~s}, 2 \mathrm{H}), 8.86(\mathrm{~d}, J=8.5 \mathrm{~Hz}, 2 \mathrm{H}), 8.68(\mathrm{~s}, 2 \mathrm{H}), 7.96(\mathrm{~d}, J=9.0 \mathrm{~Hz}, 2 \mathrm{H})$, $7.88(\mathrm{~d}, J=8.1 \mathrm{~Hz}, 2 \mathrm{H}), 7.54-7.50(\mathrm{~m}, 2 \mathrm{H}), 7.46(\mathrm{~d}, J=9.0 \mathrm{~Hz}, 2 \mathrm{H}), 7.41-7.37$ $(\mathrm{m}, 2 \mathrm{H}), 4.17(\mathrm{t}, J=6.1 \mathrm{~Hz}, 4 \mathrm{H}), 1.78(\mathrm{tt} ; J=6.1,6.1 \mathrm{~Hz} ; 4 \mathrm{H})$ and $1.49-1.37$ (m, 8H) p.p.m.; ${ }^{13} \mathrm{C}$ NMR $\left(100 \mathrm{MHz}, 298 \mathrm{~K}, \mathrm{CDCl}_{3}\right) \delta 155.9,154.4,131.6$, $130.8,128.7,128.4,127.5,125.6,123.8,114.6,113.4,69.0,28.8,28.7$ and 25.5 p.p.m.; FAB-HRMS (matrix/NBA) calcd. for $\mathrm{C}_{30} \mathrm{H}_{33} \mathrm{~N}_{2} \mathrm{O}_{4}[\mathrm{M}+\mathrm{H}]^{+}$: 485.2440, found: 485.2437 .

Synthesis of $1 . \mathrm{Et}_{3} \mathrm{~N}(861 \mu \mathrm{l}, 6.18 \mathrm{mmol})$ and $N$-chlorosuccinimide $(825 \mathrm{mg}$, $6.18 \mathrm{mmol})$ were added to a mixture of ditopic oxime $\mathbf{G}(1.00 \mathrm{~g}, 2.06 \mathrm{mmol})$ in $\mathrm{CHCl}_{3}(400 \mathrm{ml})$ at $0^{\circ} \mathrm{C}$. The mixture was heated to $60^{\circ} \mathrm{C}$ and stirred for $20 \mathrm{~min}$. The mixture was cooled to room temperature and quenched by adding water. The organic layer was dried over $\mathrm{MgSO}_{4}$, filtered and concentrated in vacuo. The crude product was purified by short flash column chromatography on silica gel $\left(\mathrm{CHCl}_{3}\right)$ to yield the ditopic nitrile $\mathrm{N}$-oxide $\mathbf{1}(716 \mathrm{mg}, 1.49 \mathrm{mmol}$, $73 \%)$ as a pale yellow solid: m.p. $119.5-120.7^{\circ} \mathrm{C}$; IR ( KBr) v 2940, 2857, 2295, $1622,1589,1510,1463,1436,1402,1339,1312,1275,1245,1156,1065,1016$, 995, 909, 806, 756, 669 and $532 \mathrm{~cm}^{-1}$; ${ }^{1} \mathrm{H}$ NMR $\left(400 \mathrm{MHz}, 298 \mathrm{~K}, \mathrm{CDCl}_{3}\right)$ $\delta 7.95(\mathrm{~d}, J=8.6 \mathrm{~Hz}, 2 \mathrm{H}), 7.92(\mathrm{~d}, J=8.9 \mathrm{~Hz}, 2 \mathrm{H}), 7.81(\mathrm{~d}, J=8.3 \mathrm{~Hz}, 2 \mathrm{H})$, $7.57(\mathrm{dd} ; J=8.6,7.1 \mathrm{~Hz} ; 2 \mathrm{H}), 7.41(\mathrm{dd} ; J=8.9,7.1 \mathrm{~Hz} ; 2 \mathrm{H}), 7.25(\mathrm{~d}, J=8.3 \mathrm{~Hz}$, $2 \mathrm{H}), 4.22(\mathrm{t}, J=6.4 \mathrm{~Hz}, 4 \mathrm{H}), 1.90(\mathrm{tt} ; J=6.4,6.4 \mathrm{~Hz} ; 4 \mathrm{H})$ and $1.59-1.47$ (m, 8H) p.p.m.; ${ }^{13} \mathrm{C}$ NMR $\left(100 \mathrm{MHz}, 298 \mathrm{~K}, \mathrm{CDCl}_{3}\right) \delta 161.3,134.5,133.1$, $128.9,128.8,128.6,125.1,124.1,113.5,96.7,69.9,34.9,29.4,29.3$ and 26.0 p.p.m.; FAB-HRMS (matrix/NBA) calcd. for $\mathrm{C}_{30} \mathrm{H}_{28} \mathrm{~N}_{2} \mathrm{O}_{4} \mathrm{Na}[\mathrm{M}+\mathrm{Na}]^{+}$: 503.1947, found: 503.1962 .

Synthesis of 1-hydroxy-4-trimethylsilylethynylbenzene $\mathbf{H}$. Trimethylsilylacetylene $(5.00 \mathrm{ml}, 36.1 \mathrm{mmol})$ was added to a suspension of $p$-iodophenol $(5.30 \mathrm{~g}, 24.5 \mathrm{mmol}), \mathrm{Pd}\left(\mathrm{PPh}_{3}\right)_{3}(844 \mathrm{mg}, 0.73 \mathrm{mmol})$ and $\mathrm{CuI}(140 \mathrm{mg}$, $0.73 \mathrm{mmol})$ in $\mathrm{Et}_{3} \mathrm{~N}(80 \mathrm{ml}) .^{21,22}$ The solution was stirred for $3 \mathrm{~h}$ at $80^{\circ} \mathrm{C}$ under an argon atmosphere, filtered and evaporated. The crude product was purified by silica gel column chromatography (hexane/ethyl acetate $=9: 1$, then 1:1) to yield $\mathbf{H}$ as a black oil $(4.07 \mathrm{~g}, 21.4 \mathrm{mmol}, 87 \%)$ : ${ }^{1} \mathrm{H}$ NMR $(400 \mathrm{MHz}$, $\left.298 \mathrm{~K}, \mathrm{CDCl}_{3}\right) \delta 7.36(\mathrm{~d}, J=8.3 \mathrm{~Hz}, 2 \mathrm{H}), 6.75(\mathrm{~d}, J=8.3 \mathrm{~Hz}, 2 \mathrm{H})$ and 0.23 (s, 9H) p.p.m.; ${ }^{13} \mathrm{C}$ NMR $\left(100 \mathrm{MHz}, 298 \mathrm{~K}, \mathrm{CDCl}_{3}\right) \delta 156.3,134.0,115.8$, $115.4,105.8,92.9$ and 0.34 p.p.m.

Synthesis of 1-ethynyl-4-hydroxybenzene $\mathrm{I} . \quad \mathrm{K}_{2} \mathrm{CO}_{3}(4.56 \mathrm{~g}, 33 \mathrm{mmol})$ was added to a solution of $\mathbf{H}(3.22 \mathrm{~g}, 16.9 \mathrm{mmol})$ in $\mathrm{MeOH}(100 \mathrm{ml}){ }^{23}$ The mixture was stirred for $3 \mathrm{~h}$ at $40{ }^{\circ} \mathrm{C}$ under an argon atmosphere and then concentrated in vacuo. Saturated aqueous $\mathrm{NaHCO}_{3}(40 \mathrm{ml})$ was added to the mixture, and the products were extracted with EtOAc. The combined organic layer was dried over $\mathrm{MgSO}_{4}$, filtered and concentrated in vacuo. The crude product was purified by short flash column chromatography on silica gel (hexane/EtOAc $=9: 1)$ to yield I $(0.649 \mathrm{~g}, 5.49 \mathrm{mmol}, 32 \%)$ as a black oil. The crude was used in the next reaction without further purification: ${ }^{1} \mathrm{H}$ NMR $\left(400 \mathrm{MHz}, 298 \mathrm{~K}, \mathrm{CDCl}_{3}\right) \delta 7.39(\mathrm{~d}, J=8.5 \mathrm{~Hz}, 2 \mathrm{H}), 6.78(\mathrm{~d}, J=8.5 \mathrm{~Hz}, 2 \mathrm{H})$, 5.17 (br, $1 \mathrm{H})$ and 2.99 (s, 1H) p.p.m.

Synthesis of 2 using $\mathbf{H} . \quad \mathrm{K}_{2} \mathrm{CO}_{3}(2.38 \mathrm{~g}, 17.2 \mathrm{mmol})$ was added to a solution of $\mathbf{H}(3.27 \mathrm{~g}, 17.2 \mathrm{mmol})$ and 1,8-dibromooctane $(1.40 \mathrm{~g}, 5.74 \mathrm{mmol})$ in DMF $(50 \mathrm{ml})$ at room temperature. The mixture was stirred at $100^{\circ} \mathrm{C}$ for $5 \mathrm{~h}$ and then filtered. The solution was purified by short flash column chromatography on silica gel (hexane/ $\mathrm{CHCl}_{3}=2: 1$ ). A tetrahydrofuran (THF) solution of tetra$n$-butylammonium fluoride (TBAF; $1 \mathrm{~mol} \mathrm{ml}^{-1}, 0.5 \mathrm{ml}$ ) was added to a THF solution of the solid $(10 \mathrm{ml})$. The solution was stirred for $1 \mathrm{~h}$ and then washed by saturated aqueous $\mathrm{NH}_{4} \mathrm{Cl}$, water and brine. The organic layer was dried over $\mathrm{MgSO}_{4}$ and concentrated in vacuo. The crude product was purified by short flash column chromatography on silica gel (hexane/ $\mathrm{CHCl}_{3}=2: 1$, then 1:1) and high-performance liquid chromatography to yield 2 (192 mg, $0.554 \mathrm{mmol}, 10 \%)$ as a white solid: IR ( $\mathrm{KBr})$ v $3299,2940,2105,1606$, $1509,1467,1291,1253,1171,1032,837$ and $610 \mathrm{~cm}^{-1}$; ${ }^{1} \mathrm{H}$ NMR $(400 \mathrm{MHz}$, $\left.298 \mathrm{~K}, \mathrm{CDCl}_{3}\right) \delta 7.41(\mathrm{~d}, J=8.3 \mathrm{~Hz}, 2 \mathrm{H}), 6.83(\mathrm{~d}, J=8.3 \mathrm{~Hz}, 2 \mathrm{H}), 3.95$ $(\mathrm{t}, J=6.5 \mathrm{~Hz}, 2 \mathrm{H}), 2.99(\mathrm{~s}, 1 \mathrm{H}), 1.78(\mathrm{tt} ; J=6.5,6.5 \mathrm{~Hz} ; 2 \mathrm{H})$ and $1.52-1.38$ (m, 4H) p.p.m.; ${ }^{13} \mathrm{C}$ NMR $\left(100 \mathrm{MHz}, 298 \mathrm{~K}, \mathrm{CDCl}_{3}\right) \delta 159.6,133.7,114.5$, $114.0,83.9,75.8,68.1,29.4,29.2$ and 26.0 p.p.m.

Synthesis of 2 using I. $\mathrm{K}_{2} \mathrm{CO}_{3}(502 \mathrm{mg}, 3.63 \mathrm{mmol})$ was added to a solution of $\mathbf{I}(300 \mathrm{mg}, 2.54 \mathrm{mmol})$ and 1,8 -dibromooctane $(0.200 \mathrm{ml}, 1.21 \mathrm{mmol})$ in DMF $(5.0 \mathrm{ml})$ at room temperature. The mixture was stirred at $100{ }^{\circ} \mathrm{C}$ for $5 \mathrm{~h}$. The mixture was cooled to room temperature, diluted with $\mathrm{Et}_{2} \mathrm{O}$, washed with water and brine, dried over $\mathrm{MgSO}_{4}$, filtered and concentrated in vacuo. The crude product was purified by short flash column chromatography on silica gel (hexane $\left./ \mathrm{CHCl}_{3}=2: 1\right)$ to yield $2(112 \mathrm{mg}, 0.323 \mathrm{mmol}, 27 \%)$ as a white solid. The crude was used in the next reaction without further purification: IR $(\mathrm{KBr})$ v 3299, 2940, 2105, 1606, 1509, 1467, 1291, 1253, 1171, 1032, 837 and $610 \mathrm{~cm}^{-1}$; ${ }^{1} \mathrm{H}$ NMR $\left(400 \mathrm{MHz}, 298 \mathrm{~K}, \mathrm{CDCl}_{3}\right) \delta 7.41(\mathrm{~d}, J=8.3 \mathrm{~Hz}, 2 \mathrm{H}), 6.83(\mathrm{~d}, J=8.3$ $\mathrm{Hz}, 2 \mathrm{H}), 3.95(\mathrm{t}, J=6.5 \mathrm{~Hz}, 2 \mathrm{H}), 2.99(\mathrm{~s}, 1 \mathrm{H}), 1.78(\mathrm{tt} ; J=6.5,6.5 \mathrm{~Hz} ; 2 \mathrm{H})$ and $1.52-1.38(\mathrm{~m}, 4 \mathrm{H})$ p.p.m.; ${ }^{13} \mathrm{C}$ NMR $\left(100 \mathrm{MHz}, 298 \mathrm{~K}, \mathrm{CDCl}_{3}\right) \delta 159.6$, 133.7, 114.5, 114.0, 83.9, 75.8, 68.1, 29.4, 29.2 and 26.0 p.p.m.

Synthesis of bisTsO-PEG J. Tosyl chloride $(13.2 \mathrm{~g}, 122 \mathrm{mmol}), \mathrm{Et}_{3} \mathrm{~N}(17.0 \mathrm{ml}$, $122 \mathrm{mmol}$ ) and DMAP (149 mg, $1.22 \mathrm{mmol}$ ) were added to a solution of PEG $\left(M_{\mathrm{n}} 2000 \mathrm{Da}, 12.2 \mathrm{~g}, 6.10 \mathrm{mmol}\right)$ in $\mathrm{CH}_{2} \mathrm{Cl}_{2}(40 \mathrm{ml})$ at $0{ }^{\circ} \mathrm{C}$. The solution was stirred for $3 \mathrm{~h}$. Excess $\mathrm{Et}_{2} \mathrm{O}$ was then added to the solution, and the mixture was cooled to $0{ }^{\circ} \mathrm{C}$. The resulting precipitate was filtered and then reprecipitated in cold EtOH. The resulting solid was collected by filtration to yield $\mathbf{J}$ $(12.4 \mathrm{~g}, 5.39 \mathrm{mmol}, 88 \%)$ as a white solid. The crude was used in the next reaction without further purification: ${ }^{1} \mathrm{H}$ NMR $\left(400 \mathrm{MHz}, 298 \mathrm{~K}, \mathrm{CDCl}_{3}\right)$ $\delta 7.79(\mathrm{~d}, J=8.4 \mathrm{~Hz}), 7.34(\mathrm{~d}, J=8.4 \mathrm{~Hz}), 4.16(\mathrm{t}, J=4.6 \mathrm{~Hz}), 3.72-3.60$ (m, $4 \mathrm{H}$ ) and 2.45 (s) p.p.m.; $T_{\mathrm{m}} 40^{\circ} \mathrm{C} ; \mathrm{T}_{\mathrm{g}}-41{ }^{\circ} \mathrm{C} ; \mathrm{T}_{\mathrm{d} 5} 235^{\circ} \mathrm{C} ; T_{\mathrm{d} 10} 251^{\circ} \mathrm{C}$.

Synthesis of 3. The product $\mathbf{J}\left(2.00 \mathrm{~g}, 0.883 \mathrm{mmol}, M_{\mathrm{n}} 2300 \mathrm{Da}\right)$ was added to a solution of $\mathbf{H}(1.00 \mathrm{~g}, 3.64 \mathrm{mmol})$ and $\mathrm{K}_{2} \mathrm{CO}_{3}(305 \mathrm{mg}, 2.21 \mathrm{mmol})$ in DMF $(10 \mathrm{ml})$ at room temperature. The solution was stirred at $80^{\circ} \mathrm{C}$ for $12 \mathrm{~h}$. Excess water was then added to the solution. The products were extracted with EtOAc, dried over $\mathrm{MgSO}_{4}$ and concentrated in vacuo. The products were reprecipitated in cold $\mathrm{MeOH}$ and subsequently dissolved in THF $(10 \mathrm{ml})$. TBAF ( $1 \mathrm{M}$ in THF, $0.2 \mathrm{ml}$ ) was added to the solution that was then stirred for 
$1 \mathrm{~h}$ at room temperature. The crude product was reprecipitated in cold $\mathrm{MeOH}$ and purified by mixing it with activated charcoal at $50^{\circ} \mathrm{C}$ for $12 \mathrm{~h}$ to yield 3 (539 mg, $0.245 \mathrm{mmol}, 28 \%)$ as a white solid: ${ }^{1} \mathrm{H}$ NMR $(400 \mathrm{MHz}, 298 \mathrm{~K}$, $\left.\mathrm{CDCl}_{3}\right) \delta 7.41(\mathrm{~d}, J=8.4 \mathrm{~Hz}), 6.85(\mathrm{~d}, J=8.4 \mathrm{~Hz}), 4.13(\mathrm{t}, J=4.6 \mathrm{~Hz}), 3.85$ $(\mathrm{t}, J=4.6 \mathrm{~Hz}), 3.76-3.56(\mathrm{~m}, 4 \mathrm{H})$ and 3.00 (s) p.p.m.; $M_{\mathrm{n}} 3100 ; M_{\mathrm{w}} 3300$; $M_{\mathrm{w}} / M_{\mathrm{n}} 1.04$ (estimated by size exclusion chromatography (SEC) using polyethylene glycol (PEG) standards); $T_{\mathrm{m}} 46^{\circ} \mathrm{C} ; T_{\mathrm{g}}-34{ }^{\circ} \mathrm{C} ; T_{\mathrm{d} 5} 360^{\circ} \mathrm{C}$; $T_{\mathrm{d} 10} 377^{\circ} \mathrm{C}$.

Synthesis of bisTsO-PTHF K. TsCl $(9.53 \mathrm{~g}, 50.0 \mathrm{mmol}), \mathrm{Et}_{3} \mathrm{~N}(6.97 \mathrm{ml}$, $50.0 \mathrm{mmol})$ and DMAP $(61.1 \mathrm{mg}, 0.500 \mathrm{mmol})$ were added to a solution of polyTHF $\left(M_{\mathrm{n}} 2900 \mathrm{Da}, 14.5 \mathrm{~g}, 5.00 \mathrm{mmol}\right)$ in $\mathrm{CH}_{2} \mathrm{Cl}_{2}(30 \mathrm{ml})$ at $0{ }^{\circ} \mathrm{C}$, and the solution was stirred for $3 \mathrm{~h}$. The crude product was precipitated in cold $\mathrm{MeOH}$. The resulting solid was filtered to yield $\mathbf{K}(11.7 \mathrm{~g}, 3.66 \mathrm{mmol}, 73 \%)$ as a white solid. The crude was used in the next reaction without further purification: ${ }^{1} \mathrm{H}$ NMR $\left(400 \mathrm{MHz}, 298 \mathrm{~K}, \mathrm{CDCl}_{3}\right) \delta 7.78(\mathrm{~d}, J=8.2 \mathrm{~Hz}), 7.34(\mathrm{~d}, J=8.2 \mathrm{~Hz})$, $4.05(\mathrm{t}, J=6.4 \mathrm{~Hz}), 3.58-3.33(\mathrm{~m}, 4 \mathrm{H}), 2.45(\mathrm{~s})$ and $1.75-1.39$ (m, 4H) p.p.m.; $T_{\mathrm{d} 5} 190^{\circ} \mathrm{C} ; T_{\mathrm{d} 10} 202^{\circ} \mathrm{C}$.

Synthesis of 4. The compound $\mathrm{O}\left(5.00 \mathrm{~g}, M_{\mathrm{n}} 3200 \mathrm{Da}, 1.56 \mathrm{mmol}\right)$ was added to a solution of $\mathbf{H}(1.28 \mathrm{~g}, 4.68 \mathrm{mmol})$ and $\mathrm{K}_{2} \mathrm{CO}_{3}(305 \mathrm{mg}, 2.21 \mathrm{mmol})$ in DMF $(10 \mathrm{ml})$ at room temperature. The solution was stirred at $100{ }^{\circ} \mathrm{C}$ for $6 \mathrm{~h}$. The precipitate obtained from immersion in cold $\mathrm{MeOH}$ was dissolved in THF $(10 \mathrm{ml})$, and a THF solution of TBAF $\left(1 \mathrm{~mol} \mathrm{ml}^{-1}, 0.2 \mathrm{ml}\right)$ was then added. The solution was stirred for $1 \mathrm{~h}$. The crude product was reprecipitated from cold $\mathrm{MeOH}$ and purified by mixing it with activated charcoal at $50^{\circ} \mathrm{C}$ for $12 \mathrm{~h}$ to yield $4(3.13 \mathrm{~g}, 1.01 \mathrm{mmol}, 65 \%)$ as a white solid. The crude was used in subsequent reaction without further purification: ${ }^{1} \mathrm{H}$ NMR $(400 \mathrm{MHz}, 298 \mathrm{~K}$, $\left.\mathrm{CDCl}_{3}\right) \delta 7.41(\mathrm{~d}, J=8.8 \mathrm{~Hz}), 6.82(\mathrm{~d}, J=8.8 \mathrm{~Hz}), 3.98(\mathrm{t}, J=6.1 \mathrm{~Hz})$, 3.48-3.35 (m, 4H), $2.99(\mathrm{~s}, 2 \mathrm{H})$ and 1.89-1.50 (m, 4H) p.p.m.; $M_{\mathrm{n}} 3200$; $M_{\mathrm{w}} 4200 ; M_{\mathrm{w}} / M_{\mathrm{n}} 1.34$ (estimated by SEC using PEG standards); $T_{\mathrm{m}} 32^{\circ} \mathrm{C}$; $T_{\mathrm{g}}-71{ }^{\circ} \mathrm{C} ; T_{\mathrm{d} 5} 334{ }^{\circ} \mathrm{C} ; T_{\mathrm{d} 10} 349^{\circ} \mathrm{C}$.

Typical procedure for the polycycloaddition of homoditopic nitrile $\mathrm{N}$-oxide 1 to a dialkyne: synthesis of polyisoxazole poly-1. A solution of $\mathbf{1}(210 \mathrm{mg}$, $0.436 \mathrm{mmol}$ ) and 1,8-bis(4-ethynylphenoxy)octane ( $151 \mathrm{mg}, 0.436 \mathrm{mmol})$ in $\mathrm{CHCl}_{3}(300 \mu \mathrm{l})$ was refluxed for $20 \mathrm{~h}$. The crude was reprecipitated in $\mathrm{MeOH}$ to give a solid that was filtered and dried in vacuo at room temperature for $12 \mathrm{~h}$ to yield poly-1 ( $362 \mathrm{mg}, 0.438 \mathrm{mmol}$, quant.) as a brown solid: IR ( $\mathrm{KBr}) \mathrm{v}$ $3437,2931,1615,1512,1250,1063$ and $807 \mathrm{~cm}^{-1}$; ${ }^{1} \mathrm{H}$ NMR $(400 \mathrm{MHz}, 298 \mathrm{~K}$, $\left.\mathrm{CDCl}_{3}\right) \delta 7.96(\mathrm{~d}, J=8.6 \mathrm{~Hz}, 2 \mathrm{H}), 7.89(\mathrm{~d}, J=9.1 \mathrm{~Hz}, 2 \mathrm{H}), 7.78(\mathrm{~d}, J=7.4 \mathrm{~Hz}$, $2 \mathrm{H}), 7.73(\mathrm{~d}, J=8.7 \mathrm{~Hz}, 4 \mathrm{H}), 7.45-7.27(\mathrm{~m}, 6 \mathrm{H}), 6.91(\mathrm{~d}, J=8.7 \mathrm{~Hz}, 4 \mathrm{H}), 6.57$ (s, 2H), 4.04-3.98 (m, 4H), 3.93-3.49 (m, 4H), 1.76-1.66 (m, 4H), 1.63-1.58 $(\mathrm{m}, 4 \mathrm{H})$ and 1.43-1.11 (m, 12H) p.p.m.; $M_{\mathrm{n}} 30000 \mathrm{Da} ; M_{\mathrm{w}} 51000 \mathrm{Da} ; M_{\mathrm{w}} / M_{\mathrm{n}}$ 1.70 (estimated by SEC using polystyrene (PS) standards); $M_{\mathrm{n}} 12000 \mathrm{Da} ; M_{\mathrm{w}}$ $21000 \mathrm{Da} ; M_{\mathrm{w}} / M_{\mathrm{n}} 1.81$ (estimated by SEC using PEG standards); $T_{\mathrm{m}} 90.3^{\circ} \mathrm{C}$ $T_{\mathrm{d} 5} 323^{\circ} \mathrm{C} ; T_{\mathrm{d} 10} 336^{\circ} \mathrm{C}$.
PEG-1: IR (KBr) v 2875, 1619, 1512, 1463, 1351, 1252, 1108, 951 and $843 \mathrm{~cm}^{-1}$; ${ }^{1} \mathrm{H}$ NMR $\left(400 \mathrm{MHz}, 298 \mathrm{~K}, \mathrm{CDCl}_{3}\right) \delta$ 7.97-7.75 (m), 7.46-7.27 (m), 7.01-6.96 (m), $6.60(\mathrm{~s}), 4.13-3.47(\mathrm{~m}, 4 \mathrm{H})$ and 1.65-1.17 (m) p.p.m.; $M_{\mathrm{n}}$ $16000 \mathrm{Da} ; M_{\mathrm{w}} 25000 \mathrm{Da} ; M_{\mathrm{w}} / M_{\mathrm{n}} 1.60$ (estimated by SEC using PEG standards); $T_{\mathrm{m}} 38.9^{\circ} \mathrm{C} ; T_{\mathrm{d} 5} 277^{\circ} \mathrm{C} ; T_{\mathrm{d} 10} 316^{\circ} \mathrm{C}$.

PTHF-1: IR (NaCl) v 2939, 2855, 2795, 1616, 1509, 1446, 1367, 1248, 1113 , 810 and $749 \mathrm{~cm}^{-1} ;{ }^{1} \mathrm{H}$ NMR $\left(400 \mathrm{MHz}, 298 \mathrm{~K}, \mathrm{CDCl}_{3}\right) \delta 7.98-7.91(\mathrm{~m})$, 7.83-7.74 (m), 7.49-7.29 (m), 6.95-6.93 (m), $6.60(\mathrm{~s}), 4.21-3.22(\mathrm{~m}, 4 \mathrm{H})$ and $1.89-1.17$ (m, 4H) p.p.m.; $M_{\mathrm{n}} 7500 \mathrm{Da} ; M_{\mathrm{w}} 12000 \mathrm{Da} ; M_{\mathrm{w}} / M_{\mathrm{n}} 1.66$ (estimated by SEC using PEG standards); $T_{\mathrm{m}} 24.9^{\circ} \mathrm{C} ; T_{\mathrm{d} 5} 269^{\circ} \mathrm{C} ; T_{\mathrm{d} 10} 295^{\circ} \mathrm{C}$.

Typical procedure for reducing the polyisoxazoles: synthesis of poly(enaminoketone) poly-2. $\mathrm{Mo}(\mathrm{CO})_{6}(79.7 \mathrm{mg}, 0.302 \mathrm{mmol})$ was added to a mixture of poly-1 $(250 \mathrm{mg}, 0.302 \mathrm{mmol})$ in DMF $(10 \mathrm{ml})$ and water $(1.0 \mathrm{ml})$. The mixture was heated to $90{ }^{\circ} \mathrm{C}$ and stirred for $12 \mathrm{~h}$. The crude mixture was reprecipitated in $\mathrm{Et}_{2} \mathrm{O}$ to give a solid that was dried in vacuo at room temperature for $12 \mathrm{~h}$ to yield poly-2 $(75.6 \mathrm{mg}, 0.0910 \mathrm{mmol}, 30 \%)$ as a brown solid: IR (KBr) v 3458, 2931, 2855, 1595, 1503, 1464, 1380, 1503, 1464, 1380, $1247,1170,1072,1020,809,785$ and $749 \mathrm{~cm}^{-1} ;{ }^{1} \mathrm{H}$ NMR $(400 \mathrm{MHz}, 298 \mathrm{~K}$, $\left.\mathrm{CDCl}_{3}\right) \delta 10.47(\mathrm{br}, 2 \mathrm{H}), 8.00-7.68(\mathrm{~m}, 10 \mathrm{H}), 7.46-7.07(\mathrm{~m}, 6 \mathrm{H}), 6.83-6.72$ $(\mathrm{m}, 4 \mathrm{H}), 5.87(\mathrm{~s}, 2 \mathrm{H}), 5.42(\mathrm{br}, 2 \mathrm{H}), 4.07-3.97(\mathrm{~m}, 4 \mathrm{H}), 3.94-3.81(\mathrm{~m}, 4 \mathrm{H})$, $1.77-1.55(\mathrm{~m}, 8 \mathrm{H})$ and $1.42-1.11$ (m, 16H) p.p.m.; $M_{\mathrm{n}} 16000 \mathrm{Da} ; M_{\mathrm{w}}$ $24000 \mathrm{Da} ; M_{\mathrm{w}} / M_{\mathrm{n}} 1.50$ (estimated by SEC using PS standards); $M_{\mathrm{n}} 5600 \mathrm{Da}$; $M_{\mathrm{w}} 8700 \mathrm{Da} ; M_{\mathrm{w}} / M_{\mathrm{n}} 1.56$ (estimated by SEC using PEG standards).

PEG-2: IR (KBr) v 2880, 1964, 1731, 1597, 1530, 1505, 1468, 1348, 1251, $1111,951,844$ and $526 \mathrm{~cm}^{-1}$; ${ }^{1} \mathrm{H}$ NMR $\left(400 \mathrm{MHz}, 298 \mathrm{~K}, \mathrm{CDCl}_{3}\right) \delta 10.49(\mathrm{br})$, 8.02-7.79 (m), 7.47-7.27 (m), 6.85-6.82 (m), $5.88(\mathrm{~s}), 5.58(\mathrm{br}), 4.09-3.46(\mathrm{~m}$, $4 \mathrm{H})$ and $1.75-1.21(\mathrm{~m})$ p.p.m.; $M_{\mathrm{n}} 9700 \mathrm{Da} ; M_{\mathrm{w}} 27000 \mathrm{Da} ; M_{\mathrm{w}} / M_{\mathrm{n}} 2.77$ (estimated by SEC using PEG standards).

PTHF-2: IR (NaCl) v 2939, 2856, 2795, 1598, 1467, 1368, 1246, 1112, 955, 808 and $750 \mathrm{~cm}^{-1}$; ${ }^{1} \mathrm{H}$ NMR $\left(400 \mathrm{MHz}, 298 \mathrm{~K}, \mathrm{CDCl}_{3}\right) \delta 10.49$ (br), 8.02-7.29 (m), 6.94-6.88 (m), $5.88(\mathrm{~s}), 4.17-3.94(\mathrm{~m}), 3.73-3.33(\mathrm{~m}, 4 \mathrm{H}), 3.32-3.24(\mathrm{~m})$, 2.01-1.54 (m, 4H) and 1.54-1.00 (m) p.p.m.; $M_{\mathrm{n}} 7900 \mathrm{Da} ; M_{\mathrm{w}} 44000 \mathrm{Da}$; $M_{\mathrm{w}} / M_{\mathrm{n}} 5.55$ (estimated by SEC using PEG standards).

Typical procedure for the complexation of a poly(enaminoketone) with $\left(\mathrm{C}_{6} \mathrm{~F}_{5}\right)_{2} \mathrm{BF}$ 5: synthesis of poly(boron enaminoketonate) poly-3. $\left(\mathrm{C}_{6} \mathrm{~F}_{5}\right)_{2} \mathrm{BF} \cdot \mathrm{OEt}_{2}(389 \mathrm{mg}, 887 \mu \mathrm{mol})$ was added to a solution of poly-2 $(73.7 \mathrm{mg}, 88.7 \mu \mathrm{mol})$ in anhydrous dichloromethane $(1.5 \mathrm{ml})$. The solution was stirred at room temperature for $2 \mathrm{~h}$. The crude product was reprecipitated in $\mathrm{Et}_{2} \mathrm{O}$ to give a solid that was dried in vacuo at room temperature for $12 \mathrm{~h}$ to yield poly-3 (133 mg, $87.6 \mu \mathrm{mol}, 99 \%)$ as a brown solid: IR $(\mathrm{NaCl})$ v 2930 , $2855,1646,1607,1558,1506,1475,1374,1259,1206,1177,1091,978$ and $807 \mathrm{~cm}^{-1} ;{ }^{1} \mathrm{H}$ NMR $\left(400 \mathrm{MHz}, 298 \mathrm{~K}, \mathrm{CDCl}_{3}\right) \delta 7.97-7.25(\mathrm{~m}, 18 \mathrm{H}), 6.91-$ $6.87(\mathrm{~m}, 4 \mathrm{H}), 6.11(\mathrm{~s}, 2 \mathrm{H}), 4.00-3.85(\mathrm{~m}, 8 \mathrm{H})$ and $1.73-1.00(\mathrm{~m}, 24 \mathrm{H})$ p.p.m.; ${ }^{19} \mathrm{~F}$ NMR $\left(400 \mathrm{MHz}, 298 \mathrm{~K}, \mathrm{CDCl}_{3}\right) \delta-136.90(\mathrm{~s}, 2 \mathrm{~F}),-157.83(\mathrm{~s}, 1 \mathrm{~F})$ and -163.69 (s, 2F) p.p.m.; elemental analysis calcd. for the $\mathrm{C}_{78} \mathrm{H}_{56} \mathrm{~B}_{2} \mathrm{~F}_{20} \mathrm{~N}_{2} \mathrm{O}_{6}$

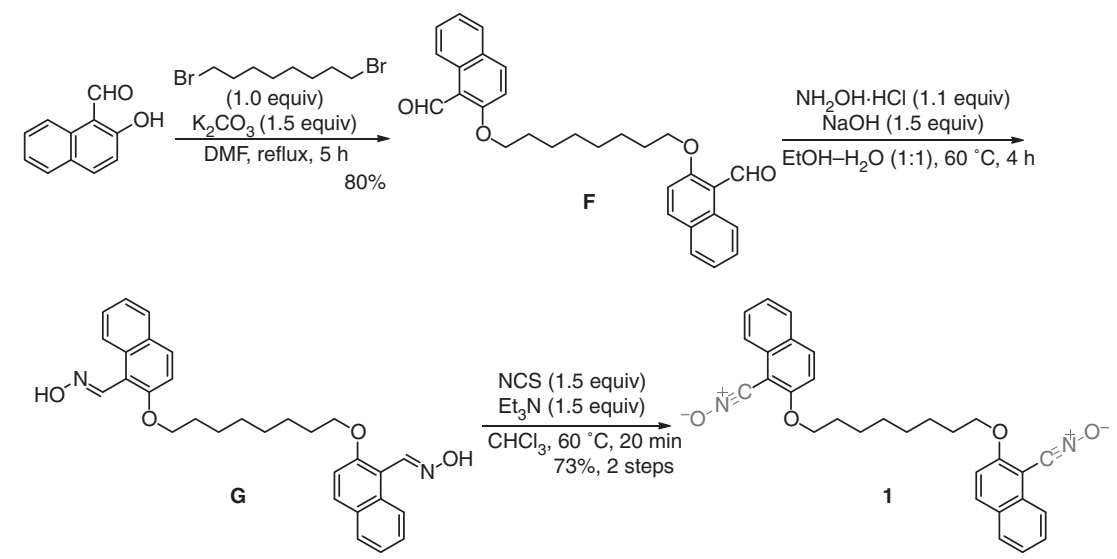

Scheme 1 Synthesis of homoditopic nitrile $\mathrm{N}$-oxide 1 . A full color version of this scheme is available at the Polymer Journal online. 

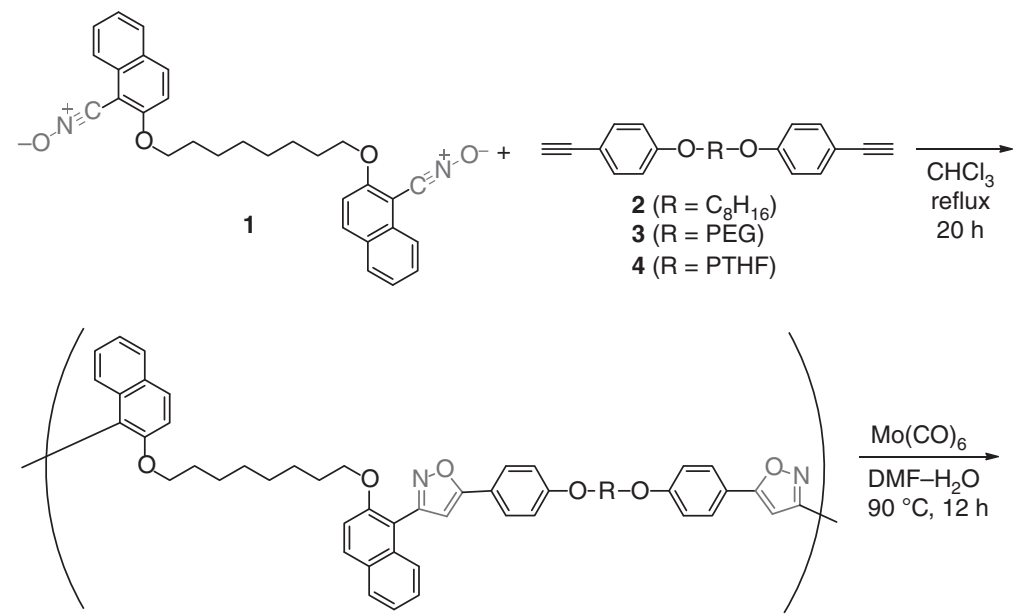

poly-1 (quant., $\mathrm{R}=\mathrm{C}_{8} \mathrm{H}_{16}$ )

PEG-1 (quant., $R=P E G$ )

PTHF-1 (87\%, R = PTHF)

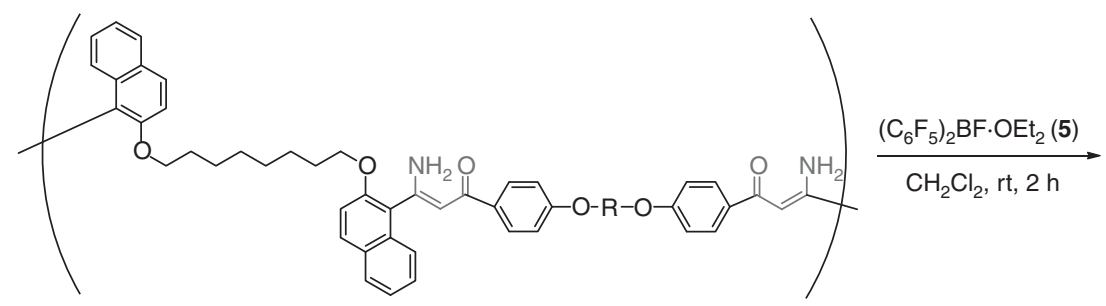

poly-2 $\left(30 \%, 96 \%\right.$ conv., $\left.\mathrm{R}=\mathrm{C}_{8} \mathrm{H}_{16}\right)$

PEG-2 (quant., 99\% conv., $\mathrm{R}=\mathrm{PEG}$ )

PTHF-2 (93\%, 99\% conv., R = PTHF)

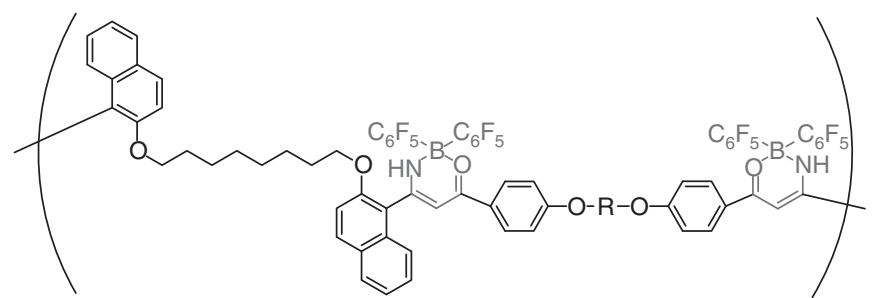

poly-3 $\left(99 \%, 99 \%\right.$ conv., $\left.\mathrm{R}=\mathrm{C}_{8} \mathrm{H}_{16}\right)$

PEG-3 (99\%, 83\% conv., $R$ = PEG)

PTHF-3 (71\%, 78\% conv., R = PTHF)

Scheme 2 Synthesis of the polyisoxazoles and their transformation into poly(boron enaminoketonate)s (PBEKs). A full color version of this scheme is available at the Polymer Journal online.

repeating unit: C 61.68, H 3.72, N 1.84, found: C 61.89, H 4.71, N 2.06; $M_{\mathrm{n}}$ $12000 ; M_{\mathrm{w}} 22000 ; M_{\mathrm{w}} / M_{\mathrm{n}} 1.84$ (estimated by SEC using PEG standards); $M_{\mathrm{n}}$ $32000 \mathrm{Da} ; M_{\mathrm{w}} 57000 \mathrm{Da} ; M_{\mathrm{w}} / M_{\mathrm{n}} 1.78$ (estimated by SEC using PS standards); $T_{\mathrm{d} 5} 276^{\circ} \mathrm{C} ; T_{\mathrm{d} 10} 293^{\circ} \mathrm{C}$.

PEG-3: IR ( $\mathrm{NaCl}) \cup$ 2871, 1605, 1505, 1471, 1349, 1254, 1105 and $969 \mathrm{~cm}^{-1}$; ${ }^{1} \mathrm{H}$ NMR $\left(400 \mathrm{MHz}, 298 \mathrm{~K}, \mathrm{CDCl}_{3}\right) \delta$ 7.97-7.26 (m), 6.96-6.93 (m), $6.13(\mathrm{~s})$, 4.13-3.43 (m, 4H) and 1.49-1.05 (m) p.p.m.; ${ }^{19} \mathrm{~F} \mathrm{NMR} \mathrm{(400} \mathrm{MHz,} 298 \mathrm{~K}$, $\left.\mathrm{CDCl}_{3}\right) \delta-136.64(\mathrm{~s}, 2 \mathrm{~F}),-157.49(\mathrm{~s}, 1 \mathrm{~F})$ and -163.55 (s, 2F) p.p.m.; elemental analysis calcd. for the $\mathrm{C}_{160.8} \mathrm{H}_{221.6} \mathrm{~B}_{2} \mathrm{~F}_{20} \mathrm{~N}_{2} \mathrm{O}_{50.4}$ repeating unit: $\mathrm{C}$ 56.96, H 6.59, N 0.83, found: C 56.33, H 6.82, N 0.86; $M_{\mathrm{n}} 12000 \mathrm{Da} ; M_{\mathrm{w}}$ $29000 \mathrm{Da} ; M_{\mathrm{w}} / M_{\mathrm{n}} 2.4$ (estimated by SEC using PEG standards); $T_{\mathrm{m}} 31.1^{\circ} \mathrm{C}$; $T_{\mathrm{d} 5} 270{ }^{\circ} \mathrm{C} ; T_{\mathrm{d} 10} 320^{\circ} \mathrm{C}$.

PTHF-3: IR ( NaCl) v 2940, 2857, 2359, 1606, 1508, 1466, 1368, 1250, 1112 and $976 \mathrm{~cm}^{-1}$; ${ }^{1} \mathrm{H}$ NMR $\left(400 \mathrm{MHz}, 298 \mathrm{~K}, \mathrm{CDCl}_{3}\right) \delta 8.00-7.27(\mathrm{~m}), 6.94-6.88$ (m), $6.12(\mathrm{~s}), 4.08-3.95(\mathrm{~m}), 3.66-3.51(\mathrm{~m}, 4 \mathrm{H}), 3.25-3.22(\mathrm{~m}), 1.98-1.56(\mathrm{~m}$, $4 \mathrm{H})$ and 1.56-1.00 (m) p.p.m.; ${ }^{19} \mathrm{~F}$ NMR $\left(400 \mathrm{MHz}, 298 \mathrm{~K}, \mathrm{CDCl}_{3}\right) \delta-136.64$ $(\mathrm{s}, 2 \mathrm{~F}),-157.50(\mathrm{~s}, 1 \mathrm{~F})$ and -163.60 (s, 2F) p.p.m.; elemental analysis calcd.

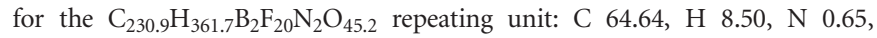
found: C 63.43, H 8.82, N $0.68 ; M_{\mathrm{n}} 3500 \mathrm{Da} ; M_{\mathrm{w}} 7300 \mathrm{Da} ; M_{\mathrm{w}} / M_{\mathrm{n}} 2.1$ (estimated by SEC using PS standards); $T_{\mathrm{m}} 22.1^{\circ} \mathrm{C} ; T_{\mathrm{d} 5} 267^{\circ} \mathrm{C} ; T_{\mathrm{d} 10} 299^{\circ} \mathrm{C}$.

\section{RESULTS AND DISCUSSION}

Synthesis of bis(nitrile N-oxide) 1 and poly(boron enaminoketonate)s

Building upon our previous study, ${ }^{24-36}$ we selected bis(2-alkoxynaphthalene nitrile $\mathrm{N}$-oxide) as a skeleton because it should be a suitable framework for a sufficiently stabilized homoditopic nitrile $\mathrm{N}$-oxide. The synthesis of the homoditopic nitrile $\mathrm{N}$-oxide $\mathbf{1}$ was accomplished with a $58 \%$ overall yield via a three-step reaction (Scheme 1, m.p. $119.5-120.7^{\circ} \mathrm{C}$ ). The structure of 1 was determined by ${ }^{1} \mathrm{H}$ NMR, ${ }^{13} \mathrm{C}$ NMR, IR and FAB-HRMS measurements (see Supplementary Materials). 
Table 1 Molecular weights of the resulting polymers

\begin{tabular}{lll}
\hline & $M_{\mathrm{w}}$ & $M_{\mathrm{w}} / M_{\mathrm{n}}$ \\
\hline $\begin{array}{lll}\text { Polyisoxazole } \\
\text { Poly-1 }\end{array}$ & $51000^{\mathrm{a}}$ & $1.7^{\mathrm{a}}$ \\
PEG-1 & $25000^{\mathrm{b}}$ & $1.6^{\mathrm{b}}$ \\
PTHF-1 & $12000^{\mathrm{a}}$ & $1.7^{\mathrm{a}}$ \\
& & \\
Poly( $\beta$-aminoenone) & & \\
Poly-2 & $24000^{\mathrm{a}}$ & $1.5^{\mathrm{a}}$ \\
PEG-2 & $27000^{\mathrm{b}}$ & $2.8^{\mathrm{b}}$ \\
PTHF-2 & $44000^{\mathrm{a}}$ & $5.6^{\mathrm{a}}$ \\
& & \\
PBEK & & $1.8^{\mathrm{a}}$ \\
Poly-3 & $57000^{\mathrm{a}}$ & $2.4^{\mathrm{b}}$ \\
PEG-3 & $29000^{\mathrm{b}}$ & $2.1^{\mathrm{a}}$ \\
PTHF-3 & $7300^{\mathrm{a}}$ & \\
\hline
\end{tabular}

aEstimated by size exclusion chromatography (SEC) analysis on the basis of polystyrene (PSt) standards (eluent: DMF).

bEstimated by SEC analysis on the basis of polyethylene glycol (PEG) standards (eluent: DMF).

Table 2 Thermal properties of the resulting polymers

\begin{tabular}{lcc}
\hline Polymer & $T_{\mathrm{m}} /{ }^{\circ} \mathrm{C}^{\mathrm{a}}$ & $T_{\mathrm{d} 5} /{ }^{\circ} \mathrm{C}^{\mathrm{b}}$ \\
\hline Poly-1 & 90.3 & 323 \\
PEG-1 & 38.9 & 277 \\
PTHF-1 & 24.9 & 269 \\
Poly-3 & $-{ }^{\mathrm{c}}$ & 276 \\
PEG-3 & 31.1 & 270 \\
PTHF-3 & 22.1 & 267 \\
\hline
\end{tabular}

a Melting temperature measured by differential scanning calorimetry (DSC).

${ }^{b} 5 \%$ Weight-loss temperature measured by thermogravimetric analysis (TGA)

${ }^{\mathrm{c}}$ Not observed.

The polycycloaddition reactions of 1 with model diyne 2 and polymeric diynes $\mathbf{3}$ and $\mathbf{4}$ were performed without a catalyst by heating in refluxing $\mathrm{CHCl}_{3}$ for $12 \mathrm{~h}$ to give the high-molecular-weight polyisoxazoles poly-1, PEG-1 and PTHF-1, respectively, in high yields (Scheme 2 and Table 1). One regioisomer was preferentially formed as confirmed by the ${ }^{1} \mathrm{H}$ NMR spectra ${ }^{16,17}$ (see Supplementary Materials). Next, the $\mathrm{N}-\mathrm{O}$ bonds of the isoxazole moiety in the resulting polyisoxazoles were cleaved using $\mathrm{Mo}(\mathrm{CO})_{6}^{37,38}$ in a $\mathrm{CH}_{3} \mathrm{CN}-\mathrm{DMF}$ mixture to give the corresponding poly $(\beta$-aminoenone)s poly-2, PEG-2 and PTHF-2 in high yields. From the integral ratio in the ${ }^{1} \mathrm{H}$ NMR spectra, it was found that nearly $100 \%$ of the $\mathrm{N}-\mathrm{O}$ bonds were successfully cleaved. Subsequent treatment of the poly $\left(\beta\right.$-aminoenone)s with $\left(\mathrm{C}_{6} \mathrm{~F}_{5}\right)_{2} \mathrm{BF} \cdot \mathrm{OEt}_{2}$ afforded PBEKs (poly-3, PEG-3 and PTHF-3) in high yields. The PBEK structures were determined by ${ }^{1} \mathrm{H}$ NMR, IR and ${ }^{19} \mathrm{~F}$ NMR spectra. The conversion of each polymer reaction was estimated to be high based on the elemental analysis results. The high reaction efficiencies for the formation of PBEKs from polyisoxazoles show that nitrile $\mathrm{N}$-oxidebased click polymer synthesis is useful. The molecular weights of all the polymers were evaluated by SEC analysis (Table 1 ). The $M_{\mathrm{w}}$ and $M_{\mathrm{w}} / M_{\mathrm{n}}$ values of the polyisoxazoles and their corresponding PBEKs were fairly consistent, indicating that the polyisoxazoles were efficiently modified without degrading the trunk polymer (see Supplementary Materials). On the other hand, the $M_{\mathrm{w}}$ and $M_{\mathrm{w}} / M_{\mathrm{n}}$ values of the $\operatorname{poly}(\beta$-aminoenone $)$ s were inconsistent with those of the other compounds. Although the precise reason for these
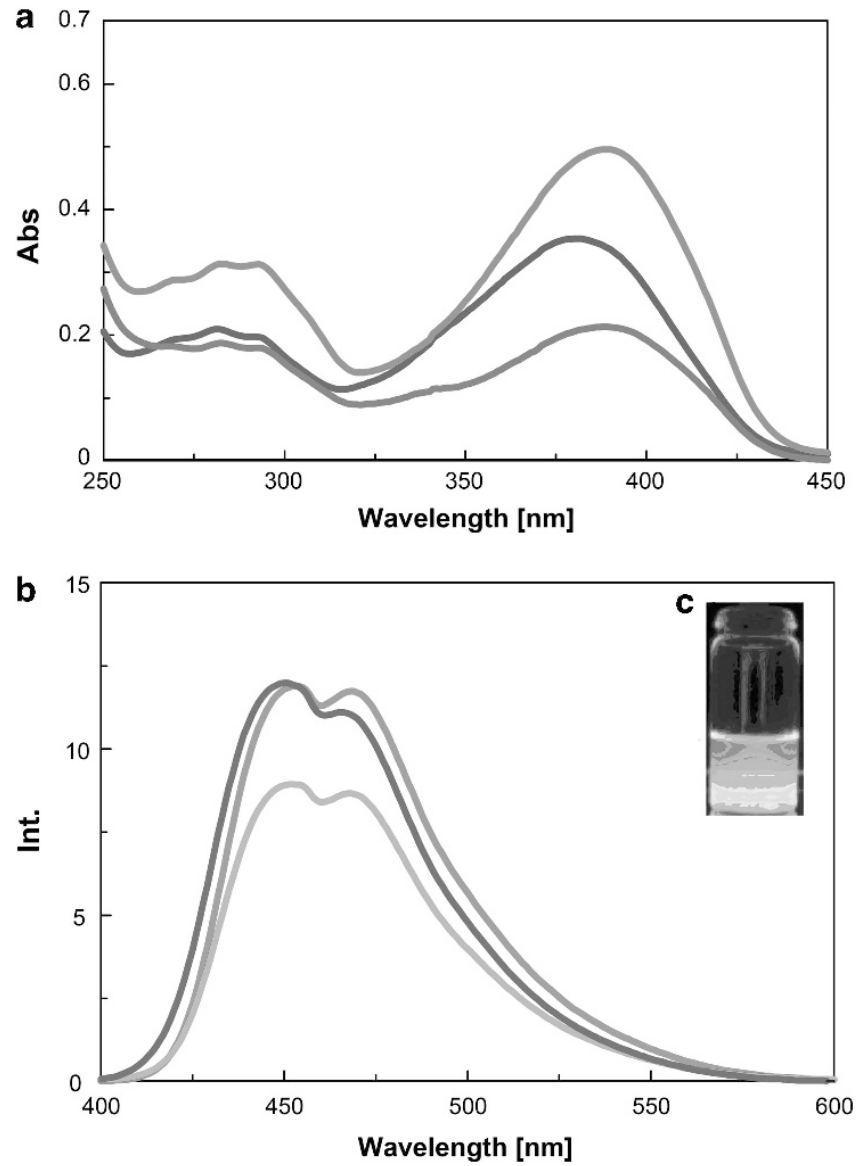

Figure 2 (a) Ultraviolet-visible (UV-vis) and (b) fluorescence spectra of poly-3 (red line), PEG-3 (blue line) and PTHF-3 (green line) (20 $\mu \mathrm{m}$ in $\mathrm{CH}_{2} \mathrm{Cl}_{2}, 293 \mathrm{~K}$ ) and photographs of $\mathrm{CH}_{2} \mathrm{Cl}_{2}$ solutions of (c) PEG-3 irradiated with $254 \mathrm{~nm}$ light. A full color version of this figure is available at the Polymer Journal online.

Table 3 Photophysical properties of poly-3, PEG-3 and PTHF-3

\begin{tabular}{lccccc}
\hline Polymer & $\lambda_{a b s}{ }^{\mathrm{a}} / \mathrm{nm}$ & $\varepsilon^{\mathrm{b}} / \mathrm{M}^{-1} \mathrm{~cm}^{-1}$ & $\lambda_{\mathrm{em}}{ }^{\mathrm{c}} / \mathrm{nm}$ & $\begin{array}{c}\text { Quantum } \\
\text { yield }\left(\Phi_{F}\right)^{\mathrm{d}}\end{array}$ & $\begin{array}{c}\text { Stokes } \\
\text { shifte } / \mathrm{cm}^{-1}\end{array}$ \\
\hline Poly-3 $^{\mathrm{f}}$ & 388 & $2.6 \times 10^{4}$ & 453 & 0.04 & $1.5 \times 10^{5}$ \\
Poly-3 $^{\mathrm{g}}$ & - & - & 499 & 0.04 & - \\
PEG-3 $^{\mathrm{f}}$ & 380 & $1.8 \times 10^{4}$ & 451 & 0.05 & $1.4 \times 10^{5}$ \\
PEG-3 $^{\mathrm{g}}$ & - & - & 467 & 0.04 & - \\
PTHF-3 $^{f}$ & 389 & $1.1 \times 10^{4}$ & 452 & 0.07 & $1.6 \times 10^{5}$ \\
6 & 389 & $1.9 \times 10^{4}$ & 452 & 0.06 & $1.6 \times 10^{5}$ \\
\hline
\end{tabular}

absorption maximum.

${ }^{b}$ Molar absorption coefficient.

'Emission maximum excited at the absorption maximum.

${ }^{d}$ Based on the fluorescent intensity of 9,10-diphenylanthracene as a reference standard. ${ }^{11}$ eEstimated by using the absorption maximum of the ultraviolet-visible (UV-vis) spectrum and the fluorescence maximum at the shorter wavelength region of the bimodal peak.

fIndicates $20 \mu \mathrm{M}, \mathrm{CH}_{2} \mathrm{Cl}_{2}, 293 \mathrm{~K}$.

gSolid-state emission was estimated in an emulsion prepared by a mixture of cyclohexane and $\mathrm{CH}_{2} \mathrm{Cl}_{2}(25: 2)$.

discrepancies is not clear, this might be attributed to a partial interchain aggregation of the $\beta$-aminoenone moieties and/or strong interactions between the $\beta$-aminoenone moieties and the SEC stationary phase. 


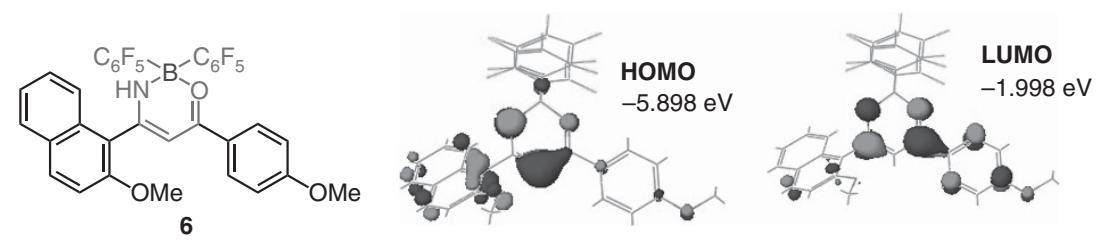

Figure 3 Structure and molecular orbital diagram of the highest occupied molecular orbital (HOMO) and lowest unoccupied molecular orbital (LUMO) of model compound 6 calculated with density functional theory (DFT; B3LYP/6-31G). A full color version of this figure is available at the Polymer Journal online.

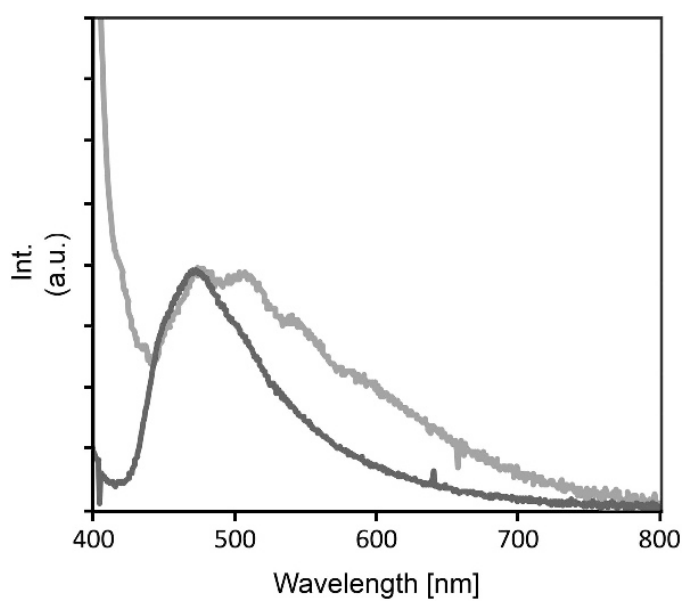

Figure 4 Solid-state fluorescence spectra of poly-3 (red line) and PEG-3 (blue line). A full color version of this figure is available at the Polymer Journal online.

\section{Thermal and optical properties of PBEKs}

Table 2 summarizes the thermal properties of the resulting polymers. All the polyisoxazoles and PBEKs, except for poly-3, were crystalline polymers, as suggested by their observed melting temperatures. ${ }^{16}$ Their crystallinity can be attributed to the interactions between the aromatic groups in the polymer main chain. The sufficiently high thermal decomposition temperatures indicated that the resulting polymers were stable.

Figure 2 shows the UV-vis and fluorescence spectra of the PBEKs in a $\mathrm{CH}_{2} \mathrm{Cl}_{2}$ solution, and Table 3 summarizes the results. For each of the PBEKs, the UV-vis absorption maximum occurred at nearly the same wavelength with a high molar absorption coefficient $(\varepsilon)$ of $\sim 380-389 \mathrm{~nm}$ (Table 3). The Stokes shifts were sufficiently high, suggesting that the boron enaminoketonate skeleton could be successfully used in molecular probes.

The $\mathrm{CH}_{2} \mathrm{Cl}_{2}$ solutions of the polymers exhibited photoluminescence emission maxima at $\sim 451-453 \mathrm{~nm}$ when excited at their absorption maxima. The fluorescence quantum yields $\left(\Phi_{\mathrm{F}}\right)$ of poly3, PEG-3 and PTHF-3 were 0.04, 0.05 and 0.07, respectively. ${ }^{39}$ These $\Phi_{\mathrm{F}}$ values are consistent with those of the poly(boron diketonate)s reported by Chujo and colleagues. ${ }^{10-12}$ To understand the PBEK photophysical properties, model compound $\mathbf{6}$ was prepared (Figure 3), and its UV-vis and fluorescence spectra were measured (see Supplementary Materials). The UV-vis absorption maximum of 6 was observed at $389 \mathrm{~nm}$ with a high molar absorption coefficient $\left(\varepsilon=1.9 \times 10^{4} \mathrm{M}^{-1} \mathrm{~cm}^{-1}\right)$.

In addition, the emission maximum and fluorescence quantum yield $\left(\Phi_{\mathrm{F}}\right)$ of $\mathbf{6}$ were $452 \mathrm{~nm}$ and 0.06 , respectively (see Supplementary Materials). These photophysical properties were in good agreement with those of the PBEKs, suggesting that the neighboring chromophore (boron enaminoketonate skeleton and naphthyl) units within the PBEKs did not interact in the ground and excited states. These results also show that the sequential transformation of the polyisoxazole allows the boron enaminoketonate skeleton to be efficiently introduced into the polymer framework.

The electronic states of $\mathbf{6}$ were also investigated with density functional theory at the B3LYP/6-31G level of the theory (Figure 3). The calculated highest occupied molecular orbital and lowest unoccupied molecular orbital of 6 were mainly located on the $\pi$ orbital of the boron enaminoketonate moiety, indicating that the lowest excited state of 6 is the $\pi-\pi^{*}$ excited state. ${ }^{11,15}$ In addition, the naphthalene moiety of $\mathbf{6}$ minimally affected the $\pi$ extension of the emissive framework because of the distorted structure.

To evaluate the solid-state PBEK emission spectra, we estimated the fluorescence spectra of emulsified poly-3 and PEG-3. The emulsions were prepared by precipitating a $\mathrm{CH}_{2} \mathrm{Cl}_{2}$ solution of the polymer into excess cyclohexane, a poor solvent. As a result, these spectra exhibited broad peaks because of polymer aggregation (Figure 4). Both solidstate $\Phi_{\mathrm{F}}$ values were approximately the same as those obtained in solution without collisional quenching of the excited state by $\pi-\pi$ stacking. ${ }^{40}$

\section{CONCLUSIONS}

In conclusion, we developed a procedure for synthesizing PBEKs by using stable homoditopic nitrile $N$-oxide $\mathbf{1}$ in a catalyst-free click polymerization and performing subsequent polymer transformations. Good optical properties, such as large Stokes shifts and $\Phi_{\mathrm{F}}$ values, were obtained and were the same as those of poly(boron diketonate)s, and this indicates that the BEK skeleton is a useful substitute for boron diketonates. The results are broadly applicable to not only polymeric materials but also supramolecular chemistry because we previously reported the effective synthesis of rotaxanes and polyrotaxanes via cycloaddition reactions involving stable nitrile $N$-oxides. ${ }^{16,27,30,33,36}$ The study of stimuli-responsive fluorescence switching systems using BEK-containing supramolecular skeletons is an important area of future research.

\section{CONFLICT OF INTEREST}

The authors declare no conflict of interest.

\section{ACKNOWLEDGEMENTS}

This work was supported by JSPS KAKENHI Grant Numbers 24685023 and 25102510 .

1 Halik, M. \& Hartmann, H. Synthesis and characterization of new long-wavelengthabsorbing oxonol dyes from the 2,2-difluoro-1,3,2-dioxaborine type. Chem. Eur. J. 5, 2511-2517 (1999).

2 Cogné-Laage, E., Allemand, J.-F., Ruel, O., Baudin, J.-B., Croquette, V., Blanchard-Desce, M. \& Jullien, L. Diaroyl(methanato)boron difluoride compounds as 
medium-sensitive two-photon fluorescent probes. Chem. Eur. J. 10, 1445-1455 (2004).

3 Ono, K., Yoshikawa, K., Tsuji, Y., Yamaguchi, H., Uozumi, R., Tomura, M., Taga, K. \& Saito, K. Synthesis and photoluminescence properties of $\mathrm{BF}_{2}$ complexes with 1,3-diketone ligands. Tetrahedron 63, 9354-9358 (2007).

4 Maeda, H., Mihashi, Y. \& Haketa, Y. Heteroaryl-substituted $C_{3}$-bridged oligopyrroles: potential building subunits of anion-responsive $\pi$-conjugated oligomers. Org. Lett. 10 , 3179-3182 (2008).

5 Haugland, R. P. The Handbook-A Guide to Fluorescent Probes and Labeling Technologies. 10th ed (ed. Spence, M. T. Z.) Chapter 1, Section 1.4 (Molecular Probes, Eugene, OR, 2005).

6 Pavlopoulos, T. G., Boyer, J. H. \& Sathyamoorthi, G. Laser action from a 2,6,8-position trisubstituted 1,3,5,7-tetramethylpyrromethene- $\mathrm{BF}_{2}$ complex: part 3. Appl. Opt. 37, 7797-7800 (1998)

7 Sanchez-Barragan, I., Costa-Fernandez, J. M., Sanz-Medel, A., Valledor, M. \& Campo, J. C. Room-temperature phosphorescence (RTP) for optical sensing. Trends Anal. Chem 25, 958-967 (2006).

8 Galletta, M., Puntoriero, F., Campagna, S., Chiorboli, C., Quesada, M., Goeb, S. \& Ziessel, R. Absorption spectra, photophysical properties, and redox behavior of ruthenium(II) polypyridine complexes containing accessory dipyrromethene- $\mathrm{BF}_{2}$ chromophores. J. Phys. Chem. A 110, 4348-4358 (2006).

9 Zhang, G., Chen, J., Payne, S. J., Kooi, S. E., Demas, J. N. \& Fraser, C. L. Multi-emissive difluoroboron dibenzoylmethane polylactide exhibiting intense fluorescence and oxygen-sensitive room-temperature phosphorescence. J. Am. Chem. Soc. 129, 8942-8943 (2007)

10 Nagai, A., Kokado, K., Nagata, Y. \& Chujo, Y. 1,3-Diketone-based organoboron polymers: emission by extending $\pi$-conjugation along a polymeric ligand. Macromolecules 41, 8295-8298 (2008)

11 Nagai, A., Kokado, K., Nagata, Y., Arita, M. \& Chujo, Y. Highly intense fluorescent diarylboron diketonate. J. Org. Chem. 73, 8605-8607 (2008).

12 Tanaka, K., Tamashima, K., Nagai, A., Okawa, T. \& Chujo, Y. Facile modulation of optical properties of diketonate-containing polymers by regulating complexation ratios with boron. Macromolecules 46, 2969-2975 (2013).

13 Xia, M., Wu, B. \& Xiang, G. Synthesis, structure and spectral study of two types of novel fluorescent BF2 complexes with heterocyclic 1,3-enaminoketone ligands. J. Fluorine Chem. 129, 402-408 (2008).

14 Macedo, F. P., Gwengo, C., Lindeman, S. V., Smith, M. D. \& Gardinier, J. R. $\beta$-diketonate, $\beta$-ketoiminate, and $\beta$-diiminate complexes of difluoroboron. Eur. J. Inorg. Chem. 2008, 3200-3211 (2008).

15 Yoshii, R., Nagai, A., Tanaka, K. \& Chujo, Y. Highly emissive boron ketoiminate derivatives as a new class of aggregation-induced emission fluorophores. Chem. Eur. J. 19, 4506-4512 (2013).

16 Koyama, Y., Matsumura, T., Yui, T., Ishitani, O. \& Takata, T. Fluorescence contro of boron enaminoketonate using a rotaxane shuttle. Org. Lett. 15, 4686-4689 (2013).

17 Lee, Y.-G., Koyama, Y., Yonekawa, M. \& Takata, T. New click chemistry: polymerization based on 1,3-dipolar cycloaddition of a homo ditopic nitrile $\mathrm{N}$-oxide and transformation of the resulting polymers into reactive polymers. Macromolecules 42, 7709-7717 (2009).

18 Koyama, Y., Seo, A. \& Takata, T. Polymer modification exploiting stable nitrile $\mathrm{N}$-oxide. Nippon Gomu Kyokaishi 84, 111-116 (2011).

19 Cai, M., Sha, J. \& Xu, Q. MCM-supported bidentate phosphine palladium(0) complex: a highly active and recyclable catalyst for the Sonogashira reaction of aryl iodides. Tetrahedron 63, 4642-4647 (2007)

20 Yoshino, J., Kano, N. \& Kawashima, T. Synthesis of the most intensely fluorescent azobenzene by utilizing the B-N interaction. Chem. Commun. 43, 559-561 (2007).

21 Duchateau, R., Lancaster, S. J., Thornton-Pett, M. \& Bochmann, M. Synthesis of Cyclopentadienyl-, Indenyl-, and Fluorenylbis(pentafluorophenyl)boranes as ligands in titanium and zirconium half-sandwich complexes. The crystal structures of $\left[\mathrm{C}_{13} \mathrm{H}_{9} \mathrm{~B}\left(\mathrm{C}_{6} \mathrm{~F}_{5}\right)_{2} \cdot t-\mathrm{BuNH} \mathrm{H}_{2}\right], \quad\left[\mathrm{C}_{13} \mathrm{H}_{8} \mathrm{SiMe} \mathrm{B}_{3} \mathrm{~B}\left(\mathrm{C}_{6} \mathrm{~F}_{5}\right)_{2}\right]$, and $\left\{\eta_{5}-\mathrm{C}_{5} \mathrm{H}_{4} \mathrm{~B}\left(\mathrm{C}_{6} \mathrm{~F}_{5}\right)_{2}\right\} \mathrm{TiCl}_{3}$ Organometallics 16, 4995-5005 (1997).

22 Hirose, T. \& Matsuda, K. Self-assembly of amphiphilic fluorescent dyes showing aggregate-induced enhanced emission: temperature dependence of molecular alignment and intermolecular interaction in aqueous environment. Chem. Commun. 45, 5832-5834 (2009).

23 Pirali, T., Gatti, S., Di Brisco, R., Tacchi, S., Zaninetti, R., Brunelli, E., Massarotti, A., Sorba, G., Canonico, P. L., Moro, L., Genazzani, A. A., Tron, G. C. \& Billington, R. A. Hybrid nanoparticles with $\mathrm{CO}_{2}$-responsive shells and fluorescence-labelled magnetic cores. Chem. Med. Chem. 2, 437-440 (2007).

24 Koyama, Y., Yonekawa, M. \& Takata, T. New click chemistry: click polymerization via 1,3-dipolar addition of homo-ditopic aromatic nitrile oxides formed in situ. Chem. Lett. 37, 918-919 (2008)

25 Lee, Y.-G., Yonekawa, M., Koyama, Y. \& Takata, T. Synthesis of a kinetically stabilized homoditopic nitrile $\mathrm{N}$-oxide directed toward catalyst-free click polymerization. Chem. Lett 39, 420-421 (2010).

26 Lee, Y.-G., Koyama, Y., Yonekawa, M. \& Takata, T. Synthesis of main-chain-type polyrotaxanes by new click polymerization using homoditopic nitrile $\mathrm{N}$-oxides via rotaxanation-polymerization protocol. Macromolecules 43, 4070-4080 (2010).

27 Matsumura, T., Ishiwari, F., Koyama, Y. \& Takata, T. C-C bond-forming click synthesis of rotaxanes exploiting nitrile $\mathrm{N}$-oxide. Org. Lett. 12, 3828-3831 (2010).

28 Koyama, Y. \& Takata, T. Polymer synthesis exploiting nitrile $\mathrm{N}$-oxide. Kobunshi Ronbunshu 68, 147-159 (2011).

29 Yonekawa, M., Koyama, Y., Kuwata, S. \& Takata, T. Intramolecular 1,3-dipolar cycloaddition of nitrile $\mathrm{N}$-oxide accompanied by dearomatization. Org. Lett. 14 1164-1167 (2012)

30 Jang, K., Miura, K., Koyama, Y. \& Takata, T. Catalyst- and solvent-free click synthesis of cyclodextrin-based polyrotaxanes exploiting a nitrile $\mathrm{N}$-oxide. Org. Lett. 14, 3088-3091 (2012)

31 Koyama, Y., Miura, K., Cheawchan, S., Seo, A. \& Takata, T. Cascade functionalization of unsaturated bond-containing polymers using ambident agents possessing both nitrile $\mathrm{N}$-oxide and electrophilic functions. Chem. Commun. 48, 10304-10306 (2012).

32 Koyama, Y., Wang, C., Miura, K., Cheawchan, S., Seo, A. \& Takata, T. Development of nitrile $\mathrm{N}$-oxide agents directed toward catalyst-free solid-state modification of common polymers. Hyomen 50, 228-238 (2012).

33 Iguchi, H., Uchida, S., Koyama, Y. \& Takata, T. Polyester-containing $\alpha$-cyclodextrinbased polyrotaxanes: synthesis by living ring-opening polymerization, polypseudorotaxanation, and end capping using nitrile N-oxide. ACS Macro Lett. 2, 527-530 (2013).

34 Wang, C., Koyama, Y., Yonekawa, M., Uchida, S. \& Takata, T. Polymer nitrile N-oxides directed toward catalyst- and solvent-free click grafting. Chem. Commun. 49, 7723-7725 (2013)

35 Cheawchan, S., Koyama, Y., Uchida, S. \& Takata, T. Catalyst-free click cascade functionalization of unsaturated-bond-containing polymers using masked-ketenetethering nitrile $\mathrm{N}$-oxide. Polymer (Guildf). 54, $4501-4510$ (2013).

36 Yuki, T., Koyama, Y., Matsumura, T. \& Takata, T. Click annulation of pseudo[2]rotaxane to [2]catenane exploiting homoditopic nitrile $\mathrm{N}$-oxide. Org. Lett. 15, 4438-4441 (2013)

37 Nitta, M. \& Higuchi, T. Mo(CO $)_{6}$-induced N-O cleavage of isoxazoles. A convenient route to pyridine-4(1H)-ones. Heterocycles 38, 853-857 (1994).

$38 \mathrm{Li}, \mathrm{C} .-\mathrm{S}$. \& Lacasse, E. Synthesis of pyran-4-ones from isoxazoles. Tetrahedron Lett 43, 3565-3568 (2002)

39 Ishida, H., Tobita, S., Hasegawa, Y., Katoh, R. \& Nozaki, K. Recent advances in instrumentation for absolute emission quantum yield measurements. Coord. Chem. Rev. 254, 2449-2458 (2010).

40 Sato, T., Jiang, D.-L. \& Aida, T. A blue-luminescent dendritic rod: poly(phenyleneethynylene) within a light-harvesting dendritic envelope. J. Am. Chem. Soc. 121, 10658-10659 (1999).

Supplementary Information accompanies the paper on Polymer Journal website (http://www.nature.com/pj) 